\title{
Effectiveness of Phages in Treating Experimental Escherichia coli Diarrhoea in Calves, Piglets and Lambs
}

\author{
By H. WILliaMS SMITH* AND M. B. HUGGINS \\ Houghton Poultry Research Station, Houghton, Huntingdon, Cambridgeshire PE17 2DA, U.K.
}

(Received 1 February 1983; revised 2 March 1983)

\begin{abstract}
A mixture of two phages, B44/1 and B44/2, protected calves against a potentially lethal oral infection with an $09: \mathrm{K} 30,99$ enteropathogenic strain of Escherichia coli, called B44, when given before, but not after, the onset of diarrhoea; a mixture in which phage B44/3 was replaced by phage B44/3 was effective after the onset of diarrhoea. Calves that responded to phage treatment had much lower numbers of $E$. coli B44 in their alimentary tract than untreated calves. Usually, high numbers of phage B44/1 and rather lower numbers of phage B44/2 or B44/3 were present in the alimentary tract of these animals. At death, most calves that had not responded to treatment with phages B44/1 and B44/2 had high numbers of mutants of $E$. coli B44 resistant to phage B44/1 in their small intestine. Phage-treated calves that survived $E$. coli infection continued to excrete phage in their faeces, at least until the numbers of $E$. coli B44 also excreted were low. The phages survived longer than $E$. coli B44 in faecal samples taken from phage-treated calves and exposed to the atmosphere in an unheated animal house. Calves inoculated orally with faecal samples from phage-treated calves that contained sufficient $E$. coli B44 to cause a lethal infection remained healthy.

A mixture of two phages, P433/1 and P433/2, and phage P433/1 alone cured diarrhoea in piglets caused by an O20:K101,987P strain of $E$. coli called P433. The numbers of the infecting bacteria and phages in the alimentary tract of the piglets resembled those in the calves. Another phage given to lambs $8 \mathrm{~h}$ after they were infected with an $08: \mathrm{K} 85,99$ enteropathogenic strain of $E$. coli, called $\mathrm{S13}$, reduced the numbers of these organisms in the alimentary tract and had an ameliorating effect on the course of the disease. No phage-resistant mutants of $E$. coli S13 were isolated from the lambs. The only mutants of $E$. coli B44 and P433 that emerged in the calves and

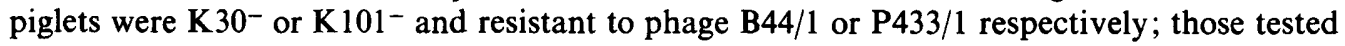
were much less virulent than their parent strains.
\end{abstract}

\section{INTRODUCTION}

Recently, an explanation for the generally held view that phages have little part to play in the treatment of bacterial infections was sought by examining the dynamics of phage/bacterium relationships in vivo (Smith \& Huggins, 1982). A generalized and a cerebral experimental infection of mice with an $018: \mathrm{K} 1: \mathrm{H}_{7} \mathrm{ColV}^{+}$strain of Escherichia coli that had caused meningitis in a human baby was used for this purpose. Contrary to expectations, an anti-K1 phage was found to be more effective in controlling these infections than most of the antibiotics with which it was compared. One reason for this was that the phage was highly active in vivo and another was that the only resistant bacterial mutants that emerged during treatment were $\mathrm{Kl}^{-}$ and of very low virulence. It seemed worthwhile to extend this approach by searching for phages that were active against $E$. coli strains that caused infections in an entirely different environment, the alimentary tract, and then studying their behaviour under experimental conditions. Infections in calves, piglets and lambs caused by three different enteropathogenic $E$. coli strains were used for this purpose. These strains proliferate in the small intestine but do not usually invade the body (Smith \& Halls, 1967). The results of the study are reported in this paper. 


\section{METHODS}

Bacterial strains. The enteropathogenic E. coli strains, B44 of antigenic formula O9:K30,99 and S13 of antigenic formula $\mathrm{O} 8: \mathrm{K} 85,99$, had been isolated from natural outbreaks of neonatal diarrhoea in calves and lambs respectively. Severe diarrhoea could be consistently produced in calves, lambs and piglets with B44 and in calves and lambs, but not piglets, with S13 provided the animals were less than $24 \mathrm{~h}$ old and when they were challenged orally with these organisms (Smith \& Halls, 1967; Smith \& Huggins, 1978). The enteropathogenic E. coli strain $\mathrm{P} 433$, of antigenic formula $\mathrm{O} 20: \mathrm{K} 101,987 \mathrm{P}$, had been received from Dr Harley Moon (his ref. 156) as having caused diarrhoea in piglets. All three strains produced heat-stable (ST) enterotoxin only. The original isolate of $E$. coli B44 was antibiotic-sensitive but in the present study a spontaneous mutant resistant to nalidixic acid ( $\mathrm{Nal}^{\mathrm{r}}$ ) was used in order to facilitate the estimation of its numbers in the alimentary tract; it was not necessary to do this in the case of $E$. coli $\mathrm{P} 433$ and $\mathrm{S} 13$ because they were naturally resistant to spectinomycin (Spcr) and ampicillin $\left(\mathrm{Ap}^{\mathrm{s}}\right)$ respectively. For the same reason, phage-resistant mutants of these strains were sometimes used as mutants resistant to other antibiotics. Phage-resistant mutants were isolated by flooding nutrient agar plates with mixtures of E. coli organisms and sufficient phage to cause confluent lysis on incubation. Colonies that grew on plates after further incubation were purified and their resistance to the phage confirmed. Antibiotic-resistant mutants were made by the method of Smith \& Huggins (1978). In oral challenge experiments, a naturally occurring tetracyclineresistant $\left(\mathrm{Tc}^{r}\right)$ non-enteropathogenic $E$. coli strain, P713, and a lactobacillus culture, AHT 1, were always given in the inoculum to simulate, to some extent, natural infection; the presence of the non-pathogenic $E$. coli strain also aided assessment of the behaviour of the enteropathogenic strain in the alimentary tract. The lactobacillus AHT 1, isolated from the faeces of a healthy pig, was not identified to species level. The antibiotic resistance of $E$. coli $\mathrm{S} 13$ and $\mathrm{P} 713$ was not transferable to $E$. coli $\mathrm{K} 12$.

Culture media and cultural conditions. Broth cultures consisted of organisms grown in $10 \mathrm{ml}$ nutrient broth, Oxoid no. 2 (CM67), in a shaking water bath (approximately 100 revolutions $\mathrm{min}^{-1}$ ). The nutrient agar employed was Difco Tryptose Agar (B64) and the MacConkey's agar was from Oxoid (CM7). When necessary, sodium citrate was added to culture media at a concentration of $2 \%(\mathrm{w} / \mathrm{v})$ and antibiotics at a concentration of $20 \mu \mathrm{g} \mathrm{ml}^{-1}$. The lactobacillus was grown on Rogosa's agar (Oxoid) for $48 \mathrm{~h}$ in an atmosphere of hydrogen containing $5 \%(\mathrm{v} / \mathrm{v}) \mathrm{CO}_{2}$. All other culture media were incubated aerobically at $37^{\circ} \mathrm{C}$ for $24 \mathrm{~h}$.

Isolation and selection of phages for in vivo studies. All phages were isolated by the method of Smith \& Huggins (1982) from different specimens of sewage. Fifteen that were lytic for $E$. coli B44 were classifiable into two groups on the basis that eight were active on a mutant of $E$. coli $\mathrm{B} 44$ selected as being resistant to one of them and seven were active on a mutant of $E$. coli $\mathrm{B} 44$ selected as being resistant to another of the phages. A calf was infected with $E$. coli $\mathrm{B} 44$ and $8 \mathrm{~h}$ later it was given an inoculum consisting of $30 \times 10^{6}$ viable particles of each of the 15 phages. After $24 \mathrm{~h}, 10 \mathrm{~g}$ of faeces was given to another calf and, after a further $24 \mathrm{~h}, 10 \mathrm{~g}$ of faeces from this calf was given to a third calf. A faecal sample $(\mathrm{lg})$ taken from this calf $24 \mathrm{~h}$ later was found to contain approximately $10^{9}$ viable particles that were active on one of the phage-resistant mutants of $E$. coli $\mathrm{B} 44$ and $10^{7}$ that were active on the other. A plaque from each of the two kinds of plates used for these phage estimations was purified and propagated on $E$. coli $\mathrm{B} 44$. The two final phage preparations were designated B44/1 and B44/2. Mutants resistant to each of these phages were fully susceptible to the other. They were fairly common in $E$. coli $\mathrm{B} 44$ as were resistant mutants to the other 13 phages. For this reason, and because it enabled their in vivo behaviour to be accurately compared, the two phages were usually given together in attempts to treat animals infected with $E$. coli $\mathrm{B} 44$. Because this combination was found ineffective in curing calves that were diarrhoeic when treatment was commenced, phage B44/2 was later replaced by a phage, B44/3, that had been classified into the same group as B44/2. Colonies of mutants resistant to phages $\mathrm{B} 44 / 2$ and $\mathrm{B} 44 / 3$ morphologically resembled those of $E$. coli $\mathrm{B} 44$; those of mutants resistant to phage B44/1 differed from them in that they were non-mucoid and $\mathrm{K}^{-} 0^{-}$. Both kinds of mutant were non-lysogenic for $E$. coli $\mathrm{B} 44$.

Escherichia coli. $\mathrm{P} 433$ infection in piglets was also usually treated with a combination of two phages, P433/1 and $\mathrm{P} 433 / 2$, selected on the basis of in vitro virulence tests. Phage P433/2 was inactive on P433 but active on phage P433/1-resistant mutants of it, mutants which were fairly common in E. coli $\mathrm{P} 433$ and which were $\mathrm{K}_{101}{ }^{-}$and nonlysogenic. A phage used for treating lambs infected with $E$. coli $\mathrm{S} 13$ was chosen because it was more virulent in vitro than 16 other S13 phages. It was used alone, because, unlike in the case of teh B44 and P433 phages, the mutation rate of $E$. coli $\mathrm{S} 13$ to resistance to this phage was so low that it could not be easily determined; mutants that were

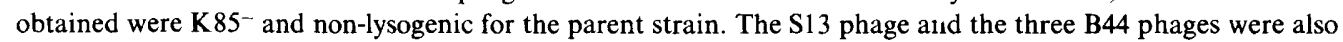
active on some strains of the same antigenic structure as $E$. coli $\mathrm{S} 13$ and B44 respectively but not on the few other calf and lamb enteropathogenic strains that were tested. Neither were the P433 phages active on pig enteropathogenic strains other than $E$. coli $\mathrm{P} 433$, the only strain of its serotype that was tested. All six phages were inactive on $\mathrm{P} 713$ and on 54 other non-enteropathogenic strains of $E$. coli isolated from calves kept on 54 different premises.

In vitro phage virulence tests. Ten $\mathrm{ml}$ amounts of nutrient broth were inoculated with $3 \times 10^{8}$ viable $E$. coli organisms and three-fold falling numbers of phage particles and incubated for $5 \mathrm{~h}$. The lowest inoculum of phage particles that produced complete clearing of the bacterial cultures was then recorded. 
Experimental animals. Calves (147 animals) were mainly from three Guernsey herds, lambs (15 animals) were from the laboratory Suffolk flock and piglets (32 animals) were from a local Large White herd. The colostrum status of the calves was confirmed by the zinc sulphate turbidity test (Aschaffenburg, 1949) and those to be used colostrum-deprived were given $100 \mathrm{ml}$ of pooled normal pig serum subcutaneously to help prevent them developing systemic infections with extraneous organisms. All the piglets and most of the lambs were received at the laboratory before they had obtained colostrum. The piglets were given $50 \mathrm{ml}$ of the same specimen of bovine colostrum; the members of each set of twin lambs were given an equal volume of colostrum, usually their mother's. The piglets were infected about $6 \mathrm{~h}$ after birth and the calves and lambs $8-16 \mathrm{~h}$ after birth. Subsequently they were fed on sterilized cows' milk given by stomach tube, twice daily in the case of calves and lambs and four times daily in the case of the piglets; at each feed, the calves received $1500 \mathrm{ml}$, the lambs $350 \mathrm{ml}$ and the piglets $50 \mathrm{ml}$.

Inoculation with $E$. coli and phage and subsequent examination of experimental animals. Calves were given $3 \times 10^{9}$ viable organisms of the $\mathrm{Nal}^{r}$ mutant of $E$. coli $\mathrm{B} 44$ together with $3 \times 10^{10}$ viable organisms of the $\mathrm{Tc}^{\mathrm{r}}$ nonenteropathogenic $E$. coli strain, P713, and $10^{10}$ viable organisms of the lactobacillus strain. Piglets were given $3 \times 10^{8}$ viable organisms of E. coli $\mathrm{P} 433,3 \times 10^{9}$ viable organisms of E. coli $\mathrm{P} 713$ and $10^{9}$ viable organisms of the lactobacillus strain. Lambs were given the same inocula as piglets except that $E$. coli $\mathrm{S} 13$ replaced $E$. coli $\mathrm{P} 433$. When phage-resistant mutants were included in the inocula they were given at the same dose as the $E$. coli strain from which they were derived. At a pre-determined time after infection, calves were given $10^{11}$ viable particles of each B44 phage, piglets $10^{10}$ viable particles of each $\mathrm{P} 433$ phage and the lambs $10^{9}$ or $10^{10}$ viable particles of the S1 3 phage. The clinical condition of the animals was assessed several times daily and the $E$. coli and the phage content of their faeces determined one or more times daily. Immediately after the animals had died or been killed by parenteral administration of sodium phenobarbitone, the concentrations of $E$. coli and phage in the contents of the abomasum or stomach, the small intestine, caecum, colon and rectum, collected in cooled nutrient broth, were estimated by a modification of the method of Miles \& Misra (1938). The small intestine was divided into seven equal parts for this purpose and the contents of each part were counted; in most animals, counts were also performed on scrapings of the washed mucous membrane of these parts.

Counts of $E$. coli were performed on plain MacConkey's agar (for the total E. coli count) and on MacConkey's agar containing such antibiotics as were necessary to distinguish all the inoculated $E$. coli strains from each other. Ten colonies from the plates used for counting the E. coli $\mathrm{B} 44, \mathrm{P} 433$ or $\mathrm{S} 13$ organisms in each sample from phagetreated animals were examined for resistance to the phages used in the treatment. (Colonies of organisms resistant to phages B44/1, P433/1 and S13 could also be differentiated from those of their parent strains by their distinctive appearance.) No $E$. coli $\mathrm{B} 44$ organisms resistant to phages $\mathrm{B} 44 / 2$ and $\mathrm{B} 44 / 3$ or $E$. coli $\mathrm{P} 433$ organisms resistant to phage P433/2 were ever found; consequently they are not referred to in the text and tables. The numbers of $E$. coli B44 in samples from calves (collected in $2 \%, \mathrm{w} / \mathrm{v}$, sodium citrate in nutrient broth) were also estimated on nutrient agar containing $2 \%$ sodium citrate in addition to an appropriate antibiotic. This permitted the enumeration of low numbers of bacteria in the presence of high numbers of phage because the B44 phages used were citrate-sensitive.

The numbers of phage were counted on plates of nutrient agar that had been spread with lawns of broth cultures of susceptible organisms; a mutant of $E$. coli B44 resistant to phages B44/2 and B44/3 was used for counting phage B44/1 and a mutant of $E$. coli B44 resistant to phage B44/1 for counting phages B44/2 and B44/3. Calf and lamb samples tested for phage content were held at $58^{\circ} \mathrm{C}$ for $30 \mathrm{~min}$; piglet samples were not so treated because the $\mathrm{P} 433 / 2$ phage was heat-sensitive. A few of the calf samples collected in sodium citrate solution were used for the B44 phage counts as well as for the bacterial counts. The heat treatment reduced their content of viable phage B44/2 of B44/3 by about 100 -fold; their content of phage B44/1 was un-altered. This reduction is corrected for in the tables; such estimates are marked ' $E$ '. The remainder of the calf samples were collected in duplicate, one into sodium citrate solution for bacterial counts and the other into plain broth for phage counts. Heat treatment of the plain broth samples had no effect on their content of viable phage B44/2 of B44/3.

\section{RESULTS}

\section{In vitro virulence of the phages used in treatment}

Judged on the number of phage particles required to lyse bacterial cultures, phage B44/1 was more virulent for $E$. coli B44 than phage B44/2 or, especially, phage B44/3; phage B44/3, though, was much more virulent than phage B44/2 for mutants of $E$. coli B44 resistant to phage B44/1 (Table 1). Phage P433/1 was highly virulent for E. coli P433 and phage P433/2 was highly virulent for mutants of $E$. coli $\mathrm{P} 433$ resistant to phage P433/1; phage P433/2 was completely inactive on $E$. coli $\mathrm{P} 433$. 
Table 1. Numbers of phages required to lyse in vitro cultures of the diarrhoea-producing E. coli and their mutants

Ten $\mathrm{ml}$ amounts of nutrient broth were inoculated with $3 \times 10^{8}$ viable $E$. coli organisms and three-fold falling numbers of phage particles and incubated for $5 \mathrm{~h}$.

\begin{tabular}{ll} 
Phage & \multicolumn{1}{c}{ E. coli strain } \\
B44/1 & B44 \\
B44/2 & B44 \\
B44/3 & B44 \\
B44/2 & B44 resistant to phage B44/1 \\
B44/3 & B44 resistant to phage B44/1 \\
P433/1 & P433 \\
P433/2 & P433 \\
P433/2 & P433 resistant to phage P433/1 \\
S13 & S13
\end{tabular}
Smallest no. of phage particles required to lyse the E. coli culture

$4 \times 10^{4}$
$4 \times 10^{5}$
$>10^{10 *}$
$2 \times 10^{3}$
6
9
Completely inactive
4
$2 \times 10^{4}$

* When broth was inoculated with $3 \times 10^{6}$ instead of $3 \times 10^{8}$ viable organisms of $E$. coli $\mathrm{B} 44$, lysis was effected by $25 \times 10^{7}$ phage particles of phage $B 44 / 3$.

\section{Effect of phage treatment in calves experimentally infected with E. coli B44}

A mixture of phages B44/1 and B44/2 had a marked curative effect when given to colostrumdeprived calves $1 \mathrm{~h}$ after infection with $E$. coli $\mathrm{B} 44$ and to colostrum-fed calves $8 \mathrm{~h}$ after infection with $E$. coli B44 (Table 2). Two of the colostrum-deprived treated calves that survived had diarrhoea but this was of short duration and occurred at a time when the number of $E$. coli B44 organisms in their faeces was not high. The mixture was much less effective when it was given at the onset of diarrhoea (usually $15-18 \mathrm{~h}$ after infection with $E$. coli B44). Much better results were obtained in these diarrhoeic calves by replacing the phage B44/2 in the mixture with B44/3, the phage that was more active in vitro against mutants of $E$. coli $\mathrm{B} 44$ resistant to phage B44/1. After treatment the condition of the animals continued to deteriorate and by $6-12 \mathrm{~h}$ a few were severely ill. Usually they then improved, by $16 \mathrm{~h}$ their diarrhoea had largely ceased and by $30 \mathrm{~h}$ they appeared normal; the survivors that had been treated with phages B44/1 and B44/2 made a much slower recovery. All except one of the 22 untreated calves ( 8 colostrum-deprived and 14 colostrum-fed) developed severe diarrhoea and died; 19 of the deaths occurred within $43 \mathrm{~h}$ of infection.

Table 2. Effect of giving mixtures of phages B44/1 and B44/2 or of phages B44/1 and B44/3 to calves at different times after they had been inoculated with E. coli B44

The calves were inoculated orally with $3 \times 10^{9}$ viable organisms of $E$. coli $\mathrm{B} 44$, together with $3 \times 10^{10}$ viable organisms of the non-pathogenic $E$. coli $\mathrm{P} 713$ and $10^{10}$ viable organisms of a lactobacillus strain. Phages B44/1 and B44/2, or B44/1 and B44/3, were given as a mixture containing $10^{11}$ viable particles of each.

\begin{tabular}{|c|c|c|c|c|c|}
\hline $\begin{array}{l}\text { No. of } \\
\text { calves }\end{array}$ & $\begin{array}{l}\text { Colostrum } \\
\text { status } \dagger\end{array}$ & $\begin{array}{c}\text { Time after } \\
\text { inoculation when } \\
\text { given phages }\end{array}$ & $\begin{array}{l}\text { No. that } \\
\text { developed } \\
\text { diarrhoea }\end{array}$ & $\begin{array}{l}\text { No. that } \\
\text { died }\end{array}$ & $\begin{array}{l}\text { Approx. survival time } \\
\text { of calves that died } \ddagger(h)\end{array}$ \\
\hline 6 & - & $1 \mathrm{~h}$ & 3 & 1 & 63 \\
\hline 8 & - & Not given & 8 & 8 & $24,28,30(2), 32,38,40,43$ \\
\hline 9 & + & $8 \mathrm{~h}$ & 0 & 0 & \\
\hline 21 & + & $\begin{array}{l}\text { At onset of } \\
\text { diarrhoea }\end{array}$ & 21 & 14 & $30(3), 35(3), 40,48,56,64,72(2), 84,108$ \\
\hline $13^{*}$ & + & $\begin{array}{l}\text { At onset of } \\
\text { diarrhoea }\end{array}$ & 13 & 2 & 24,46 \\
\hline 14 & + & Not given & 13 & 13 & $22,24(3), 30(2), 32,38(4), 76(2)$ \\
\hline
\end{tabular}

* These 13 calves were given phages B44/1 and B44/3; all the other calves were given phages B44/1 and B44/2. $\dagger+$, Colostrum-fed; - , colostrum-deprived.

$\ddagger$ The number of calves, when this was $>1$, is given in parentheses. 
Table 3. Counts on samples from colostrum-deprived calves treated or not treated with a mixture of phages B44/1 and B44/2, $1 \mathrm{~h}$ after infection with $E$. coli B44

Seven treated and seven untreated calves were examined $26-45 \mathrm{~h}$ after oral infection with $E$. coli B44, together with non-pathogenic $E$. coli P713 and lactobacilli (numbers of organisms as for Table 2). The median count is given, followed by the range in parentheses; $N=$ none found. The small intestine was divided into seven equal parts for counting; part 1 was next to the abomasum and part 7 next to the colon. In general the results for parts 2,4 and 6 were intermediate between those for parts 1 and 3,3 and 5 , and 5 and 7 respectively.

No. of bacteria or phages $\left(\log _{10}\left[\right.\right.$ no. $\left.\left.(\mathrm{g} \text { sample })^{-1}\right]\right)$

$\quad \begin{gathered}\text { Material } \\ \text { examined }\end{gathered}$
Abomasum conten
Small intestine
contents, part:
1
3
5
7
Caecal contents
Colon contents
Faeces
Intestinal lymph
node
Spleen
Blood

Material

Abomasum contents

Small intestine

contents, part:

Phage treatment of colostrum-deprived calves. Only low numbers of $E$. coli B44 were found in the alimentary tract of seven colostrum-deprived calves killed $26-45 \mathrm{~h}$ after they had been infected with these organisms and given a mixture of phages B44/1 and B44/2 $1 \mathrm{~h}$ later (Table 3). The exact time of examination of each calf coincided with the time of examination of a similar but untreated calf. Much higher numbers of $E$. coli B44 were found in the alimentary tracts of these untreated calves. These animals were either near to death or had just died when they were examined, whereas the treated calves were healthy. [Analysis of the contents of the abomasum and parts 1-6 of the small intestine of another untreated calf $1 \mathrm{~h}$ after infection with $E$. coli B44 (i.e. at the time at which phage was administered to the other calves) gave the following counts of these organisms $\left(\log _{10} \mathrm{~g}^{-1}\right): 5 \cdot 0,4 \cdot 5,4 \cdot 5,5 \cdot 5,6 \cdot 3,6 \cdot 5$ and $5 \cdot 5$; none were found in part 7 of the small intestine or in the large intestine. The total number of $E$. coli B44 found in these sites was approximately the same as the infective dose, $3 \times 10^{9}$ viable organisms.] Mutants of $E$. coli B44 resistant to phage B44/1 were frequently isolated from the alimentary tracts of the treated calves; in many of the samples they were more common than phage-sensitive B44 organisms. High numbers of phage B44/1 were present in the small intestine, especially the posterior parts, and in the large intestine of most of the treated calves. Much lower numbers of phage B44/2 were present in six of the calves. Calves examined within $35 \mathrm{~h}$ of treatment usually had larger amounts of both phages in their alimentary tract than those examined later. For example, the numbers of phage B44/1 in part 7 of the small intestine of the calves examined at $26,28,28,35$, 42,42 and $45 \mathrm{~h}$ after infection were $\left(\log _{10} \mathrm{~g}^{-1}\right) 9 \cdot 0,9 \cdot 0,7 \cdot 5,8 \cdot 2,5 \cdot 0,3 \cdot 0$ and $5 \cdot 7$ respectively. The corresponding figures for phage B44/2 were $5 \cdot 9,7 \cdot 9,8 \cdot 5,3 \cdot 0,3 \cdot 5,4 \cdot 7$ and $5 \cdot 0$ respectively. Very few $E$. coli B44 organisms or phage particles were found in an intestinal lymph node, the spleen or the blood of the treated calves.

The results of counts on the contents of the alimentary tract of seven colostrum-deprived calves $27 \mathrm{~h}$ after they had been given $E$. coli B44 and/or phages B44/1, B44/2 and B44/3 $1 \mathrm{~h}$ later are summarized in Table 4. One of the calves given $E$. coli B44 alone (no. 1) developed very severe diarrhoea and was near to death when examined. Very high numbers of $E$. coli B44 were found in its intestines. The disease in another calf given these organisms and phage B44/2 (no. 2) 
Table 4. Counts on the contents of different parts of the alimentary tract of colostrum-deprived calves orally given $E$. coli $B 44$ and/or phages B44/1,B44/2 and B44/3

The phages were given $1 \mathrm{~h}$ after $E$. coli B44, and the calves examined $27 \mathrm{~h}$ later. The numbers of $E$. coli B44, non-pathogenic $E$. coli P713, lactobacilli and phages given were as for Table 2 . In general the results for parts 2, 4 and 6 of the small intestine were intermediate between those for parts 1 and 3,3 and 5 , and 5 and 7 respectively. $\mathbf{N}=$ none found.

No. of bacteria or phages $\left(\log _{10}\left[\right.\right.$ no. $\left.\left.(\mathrm{g} \text { contents })^{-1}\right]\right)$ in:

\begin{tabular}{|c|c|c|c|c|c|c|c|c|}
\hline \multirow[b]{2}{*}{$\begin{array}{l}\text { Calf } \\
\text { no. }\end{array}$} & \multirow[b]{2}{*}{$\begin{array}{l}\text { Organisms } \\
\text { given }\end{array}$} & \multirow[b]{2}{*}{$\begin{array}{l}\text { Organisms } \\
\text { enumerated }\end{array}$} & \multirow[b]{2}{*}{ Abomasum } & \multicolumn{4}{|c|}{ Small intestine, part: } & \multirow[b]{2}{*}{ Colon } \\
\hline & & & & 1 & 3 & 5 & 7 & \\
\hline 1 & E. coli B44 & E. coli B44 & $4 \cdot 3$ & $9 \cdot 0$ & $10 \cdot 3$ & $10 \cdot 0$ & $10 \cdot 0$ & $10 \cdot 9$ \\
\hline 2 & $\begin{array}{l}\text { E. coli } \mathrm{B} 44 \\
\text { and phage } \mathrm{B} 44 / 2\end{array}$ & $\begin{array}{l}\text { E. coli } \mathrm{B} 44 \\
\text { Phage } \mathrm{B} 44 / 2\end{array}$ & $\begin{array}{l}5 \cdot 6 \\
5 \cdot 0\end{array}$ & $\begin{array}{l}9 \cdot 6 \\
6 \cdot 4\end{array}$ & $\begin{array}{l}9 \cdot 8 \\
7 \cdot 0\end{array}$ & $\begin{array}{l}9 \cdot 7 \\
7 \cdot 2\end{array}$ & $\begin{array}{r}10 \cdot 2 \\
7 \cdot 3\end{array}$ & $\begin{array}{l}9 \cdot 8 \\
7 \cdot 5\end{array}$ \\
\hline 3 & $\begin{array}{l}E \text {. coli } \mathrm{B} 44 \\
\text { and phage } \mathrm{B} 44 / 1\end{array}$ & $\begin{array}{l}\text { E. coli } \mathrm{B} 44 \\
\text { Phage B44/1 }\end{array}$ & $\begin{array}{l}\mathbf{N} \\
\mathbf{N}\end{array}$ & $\begin{array}{c}\mathrm{N} \\
2 \cdot 9\end{array}$ & $\begin{array}{l}7 \cdot 7^{*} \\
8 \cdot 4\end{array}$ & $\begin{array}{l}7 \cdot 8^{*} \\
8.9\end{array}$ & $\begin{array}{l}7 \cdot 7^{*} \\
8 \cdot 9\end{array}$ & $\begin{array}{l}6 \cdot 2^{*} \\
9 \cdot 0\end{array}$ \\
\hline 4 & $\begin{array}{l}E . \text { coli } \mathrm{B} 44 \\
\text { and phages } \\
\text { B44/1 and B44/2 }\end{array}$ & $\begin{array}{l}\text { E. coli B44 } \\
\text { Phage B44/1 } \\
\text { Phage B44/2 }\end{array}$ & $\begin{array}{l}\mathrm{N} \\
5 \cdot 3 \\
5 \cdot 0\end{array}$ & $\begin{array}{l}N \\
4 \cdot 0 \\
N\end{array}$ & $\begin{array}{l}6 \cdot 0^{*} \\
6 \cdot 7 \\
5 \cdot 6\end{array}$ & $\begin{array}{l}6 \cdot 9^{*} \\
7 \cdot 0 \\
7 \cdot 8\end{array}$ & $\begin{array}{l}7 \cdot 0^{*} \\
7 \cdot 5 \\
8 \cdot 5\end{array}$ & $\begin{array}{l}6 \cdot 7^{*} \\
7 \cdot 7 \\
8 \cdot 7\end{array}$ \\
\hline 5 & $\begin{array}{l}\text { E. coli } \mathrm{B} 44 \\
\text { B44/1 and B44/2 }\end{array}$ & $\begin{array}{l}\text { E. coli } \mathrm{B} 44 \\
\text { Phage } \mathrm{B} 44 / 2\end{array}$ & $\begin{array}{c}\mathrm{N} \\
2 \cdot 3\end{array}$ & $\begin{array}{l}2 \cdot 6 \\
2 \cdot 0\end{array}$ & $\begin{array}{l}4.9 \\
3 \cdot 0\end{array}$ & $\begin{array}{l}5 \cdot 4^{*} \\
5 \cdot 7\end{array}$ & $\begin{array}{l}5 \cdot 8^{*} \\
5 \cdot 9\end{array}$ & $\begin{array}{l}5 \cdot 6 \\
8 \cdot 6\end{array}$ \\
\hline 6 & $\begin{array}{l}E . \text { coli } \mathrm{B} 44 \\
\text { and phages } \\
\text { B44/1 and B44/3 }\end{array}$ & $\begin{array}{l}\text { E. coli B44 } \\
\text { Phage B44/1 } \\
\text { Phage B44/3 }\end{array}$ & $\begin{array}{l}\mathrm{N} \\
5 \cdot 0 \\
5 \cdot 0\end{array}$ & $\begin{array}{l}2 \cdot 9 \\
3 \cdot 7 \\
4 \cdot 3\end{array}$ & $\begin{array}{l}3 \cdot 5 \\
4 \cdot 2 \\
4 \cdot 2\end{array}$ & $\begin{array}{l}3 \cdot 5 \\
4 \cdot 7 \\
5 \cdot 0\end{array}$ & $\begin{array}{l}3 \cdot 5 \\
5 \cdot 5 \\
5 \cdot 7\end{array}$ & $\begin{array}{l}3 \cdot 5 \\
6 \cdot 7 \\
5 \cdot 0\end{array}$ \\
\hline 7 & $\begin{array}{l}\text { Phages B44/1 } \\
\text { and B44/2 }\end{array}$ & $\begin{array}{l}\text { Phage B44/1 } \\
\text { Phage B44/2 }\end{array}$ & $\begin{array}{l}3 \cdot 9 \\
4 \cdot 3\end{array}$ & $\begin{array}{l}2 \cdot 7 \\
3 \cdot 3\end{array}$ & $\begin{array}{l}\mathbf{N} \\
\mathbf{N}\end{array}$ & $\begin{array}{l}2 \cdot 0 \\
2 \cdot 8\end{array}$ & $\begin{array}{l}4 \cdot 7 \\
5 \cdot 2\end{array}$ & $\begin{array}{l}5 \cdot 3 \\
5 \cdot 6\end{array}$ \\
\hline
\end{tabular}

* Mainly mutants of $E$. coli B44 resistant to phage B44/1.

was equally severe and the $E$. coli counts in its intestines were equally high; only moderate numbers of phage B $44 / 2$ were present in its alimentary tract. A calf given $E$. coli B44 and phage B44/1 (no. 3) developed moderate diarrhoea and this was associated with the presence in its intestines of fairly high numbers of mutants of $E$. coli B44 resistant to phage B44/1; high numbers of the phage were found in its intestines. One of two calves given $E$. coli B44 and phages B44/1 and B44/2 (no. 4) had milder diarrhoea. The dominant E. coli B44 organisms in its intestines were again of the phage B44/1-resistant variety; higher numbers of phage B44/2 than of B44/1 were found in its lower small intestine and large intestine. The other calf given a similar inoculum (no. 5) and one given E. coli B44 and phages B44/1 and B44/3 (no. 6). showed little departure from normal health and both calves had low numbers of $E$. coli B44 in their intestines, many of those in no. 5, but not in no. 6, being phage B44/1-resistant. Much smaller amounts of phage were detected in the alimentary tract of a calf given phages B44/1 and B44/2 and no E. coli B44 (no. 7) than had been found in the calves given phages and $E$. coli B44; the two phages were similarly distributed throughout its alimentary tract. In general, the numbers of E. coli B44 in scrapings of the washed mucous membrane of the seven parts of the small intestine of the seven calves resembled the numbers in the intestinal contents. Except when they were low (e.g. in calf no. 7, which was given phages but not $E$. coli $\mathrm{B} 44$ ), the numbers of phage particles were usually about 10 times lower in the scrapings than in the contents; the numbers of the nonenteropathogenic E. coli P713 were 10-100 times lower in the scrapings than in the contents.

Phage treatment of colostrum-fed calves. Six colostrum-fed calves were given a mixture of phages B44/1 and B $44 / 28 \mathrm{~h}$ after they had been infected with $E$. coli B44; the results of examining these animals and six untreated calves at different times thereafter are summarized in Table 5. The numbers of E. coli B44 were much lower in the intestines of the treated calves than in the intestines of the untreated calves examined at the same time; this was particularly so in the calves examined towards the end of the experiment. One of the treated calves examined $16 \mathrm{~h}$ after infection had fairly high numbers of E. coli B44 in its small intestine, sufficiently high 
Table 5. Counts on the contents of different parts of the alimentary tract of colostrum-fed calves orally infected with $E$. coli B44, given a mixture of phages B44/1 and B44/2 8 h later and examined at different times thereafter

The numbers of $E$. coli $\mathrm{B} 44$, non-pathogenic $E$. coli $\mathrm{P} 713$, lactobacilli and phages given were as for Table 2. Bacterial counts were also performed on six control animals that received $E$. coli $\mathbf{B} 44$ but not phage $\left(\right.$ marked $\left.{ }^{*}\right)$. In general the results for parts 2,4 and 6 of the small intestine were intermediate between those for parts 1 and 3, 3 and 5, and 5 and 7 respectively. $E=$ estimate (see Methods); $N=$ none found.

No. of bacteria or phages $\left(\log _{10}\left[\right.\right.$ no. $\left.\left.(\mathrm{g} \text { contents })^{-1}\right]\right)$ in:

\section{Time after infection with B44}

(h)

\begin{tabular}{|c|c|}
\hline $8^{*}$ & E. coli $\mathrm{B} 44$ \\
\hline 10 & $\begin{array}{l}E . \text { coli } \mathrm{B} 44 \\
\text { Phage B44/1 } \\
\text { Phage B44/2 }\end{array}$ \\
\hline $10^{*}$ & E. coli $\mathrm{B} 44$ \\
\hline 12 & $\begin{array}{l}\text { E. coli B44 } \\
\text { Phage B44/1 } \\
\text { Phage B44/2 (E }\end{array}$ \\
\hline $12^{*}$ & E. coli $\mathrm{B} 44$ \\
\hline 16 & $\begin{array}{l}\text { E. coli } \mathrm{B} 44 \\
\text { Phage B44/1 } \\
\text { Phage } \mathrm{B} 44 / 2 \text { (E }\end{array}$ \\
\hline 16 & $\begin{array}{l}\text { E. coli } \mathrm{B} 44 \\
\text { Phage B44/1 } \\
\text { Phage } \mathrm{B} 44 / 2 \text { (E }\end{array}$ \\
\hline $16^{*}$ & E. coli B44 \\
\hline 20 & $\begin{array}{l}E \text {. coli } \mathrm{B} 44 \\
\text { Phage B44/1 } \\
\text { Phage B44/2 }\end{array}$ \\
\hline $20^{*}$ & E. coli $\mathrm{B} 44$ \\
\hline 24 & $\begin{array}{l}\text { E. coli B44 } \\
\text { Phage B44/1 } \\
\text { Phage B44/2 (E }\end{array}$ \\
\hline $24^{*}$ & E. coli $\mathrm{B} 44$ \\
\hline
\end{tabular}

Organisms enumerated

E. coli $\mathrm{B} 44$

\begin{tabular}{|c|c|c|c|c|c|}
\hline \multirow[b]{2}{*}{ Abomasum } & \multicolumn{4}{|c|}{ Small intestine, part: } & \multirow[b]{2}{*}{ Colon } \\
\hline & 1 & 3 & 5 & 7 & \\
\hline $4 \cdot 7$ & $5 \cdot 2$ & $6 \cdot 2$ & $6 \cdot 2$ & $9 \cdot 0$ & $8 \cdot 3$ \\
\hline $\begin{array}{l}5 \cdot 3 \\
6 \cdot 3 \\
7 \cdot 4\end{array}$ & $\begin{array}{l}5 \cdot 0 \\
6 \cdot 3 \\
6 \cdot 8\end{array}$ & $\begin{array}{l}6 \cdot 3 \\
8 \cdot 2 \\
7 \cdot 2\end{array}$ & $\begin{array}{l}6 \cdot 8 \\
8 \cdot 4 \\
7 \cdot 8\end{array}$ & $\begin{array}{l}7 \cdot 3 \\
7 \cdot 4 \\
7 \cdot 5\end{array}$ & $\begin{array}{l}8 \cdot 7 \\
\mathrm{~N} \\
\mathrm{~N}\end{array}$ \\
\hline $5 \cdot 0$ & $5 \cdot 7$ & $7 \cdot 5$ & $7 \cdot 7$ & $8 \cdot 8$ & $8 \cdot 0$ \\
\hline $\begin{array}{l}5 \cdot 7 \\
7 \cdot 3 \\
4 \cdot 8\end{array}$ & $\begin{array}{l}5 \cdot 6 \\
7 \cdot 8 \\
4 \cdot 8\end{array}$ & $\begin{array}{l}5 \cdot 0 \\
8 \cdot 7 \\
6.7\end{array}$ & $\begin{array}{l}5 \cdot 3 \\
9 \cdot 8 \\
7 \cdot 3\end{array}$ & $\begin{array}{r}6.0 \\
11.0 \\
8.5\end{array}$ & $\begin{array}{r}8 \cdot 2 \\
10 \cdot 0 \\
8 \cdot 2\end{array}$ \\
\hline $6 \cdot 0$ & 6.8 & $7 \cdot 5$ & $8 \cdot 0$ & 8.0 & $8 \cdot 0$ \\
\hline $\begin{array}{c}2 \cdot 5 \\
\mathrm{~N} \\
\mathrm{~N}\end{array}$ & $\begin{array}{l}3 \cdot 6 \\
5 \cdot 0 \\
4 \cdot 0\end{array}$ & $\begin{array}{l}5 \cdot 0 \\
6 \cdot 5 \\
4 \cdot 0\end{array}$ & $\begin{array}{l}4 \cdot 8 \\
7 \cdot 5 \\
4 \cdot 8\end{array}$ & $\begin{array}{l}4 \cdot 2 \\
8 \cdot 5 \\
6 \cdot 0\end{array}$ & $\begin{array}{l}6 \cdot 4 \\
8 \cdot 7 \\
7 \cdot 0\end{array}$ \\
\hline $\begin{array}{l}5 \cdot 6 \\
7 \cdot 5 \\
5 \cdot 0\end{array}$ & $\begin{array}{l}6.0 \\
9 \cdot 7 \\
7.0\end{array}$ & $\begin{array}{r}6 \cdot 6 \\
10 \cdot 0 \\
7 \cdot 8\end{array}$ & $\begin{array}{r}7.6 \\
10.7 \\
9.5\end{array}$ & $\begin{array}{r}8 \cdot 3 \\
11 \cdot 0 \\
9.7\end{array}$ & $\begin{array}{r}7 \cdot 5 \\
11 \cdot 0 \\
8 \cdot 3\end{array}$ \\
\hline $6 \cdot 0$ & $6 \cdot 6$ & $7 \cdot 8$ & 9.0 & $9 \cdot 7$ & $9 \cdot 5$ \\
\hline $\begin{array}{l}3 \cdot 4 \\
3 \cdot 5 \\
3 \cdot 4\end{array}$ & $\begin{array}{l}\mathrm{N} \\
\mathrm{N} \\
\mathrm{N}\end{array}$ & $\begin{array}{l}\mathrm{N} \\
2 \cdot 0 \\
2 \cdot 3\end{array}$ & $\begin{array}{l}3 \cdot 7 \\
4 \cdot 2 \\
3 \cdot 4\end{array}$ & $\begin{array}{l}5 \cdot 3 \\
6 \cdot 8 \\
4 \cdot 5\end{array}$ & $\begin{array}{l}7 \cdot 5 \\
8 \cdot 4 \\
8 \cdot 5\end{array}$ \\
\hline $6 \cdot 6$ & $6 \cdot 4$ & $9 \cdot 7$ & $9 \cdot 8$ & $9 \cdot 8$ & $9 \cdot 8$ \\
\hline $\begin{array}{l}\mathrm{N} \\
\mathrm{N} \\
\mathrm{N}\end{array}$ & $\begin{array}{l}\mathrm{N} \\
\mathrm{N} \\
\mathrm{N}\end{array}$ & $\begin{array}{l}3 \cdot 3 \\
5 \cdot 0 \\
6 \cdot 3\end{array}$ & $\begin{array}{l}4.0 \\
4.5 \\
5.0\end{array}$ & $\begin{array}{l}3 \cdot 0 \\
6 \cdot 7 \\
6 \cdot 6\end{array}$ & $\begin{array}{l}3 \cdot 0 \\
6 \cdot 6 \\
6 \cdot 0\end{array}$ \\
\hline $5 \cdot 2$ & $7 \cdot 7$ & $9 \cdot 8$ & 10.0 & $10 \cdot 0$ & $10 \cdot 0$ \\
\hline
\end{tabular}

to account for its diarrhoea; none of the other treated calves appeared unwell but the untreated ones examined at 16-24 h had severe diarrhoea. Mutants of $E$. coli B44 resistant to phage B44/1 were not isolated from any of the calves. Phages were not detected in the large intestine of the treated calf examined at $10 \mathrm{~h}(2 \mathrm{~h}$ after phage administration) but they were plentiful in the more anterior parts of the alimentary tract. Phages were present in fairly high numbers in the intestines of the other treated calves examined within $20 \mathrm{~h}$ of infection, especially the one killed at $16 \mathrm{~h}$ that had diarrhoea; phage B44/1 was usually much more common than B44/2. Phage counts were lower in the calves examined later.

Nine of the colostrum-fed calves that did not respond to treatment with phage B44/1 and $\mathrm{B} 44 / 2$ at the onset of diarrhoea (Table 2) were examined at point of death. In the small intestine of seven of them, phage B44/1-resistant mutants of $E$. coli B44 were much more plentiful than $E$. coli B44 itself, i.e. phage-sensitive $E$. coli B44. The numbers of resistant mutants were sufficiently high to have caused the deaths of the calves; much lower numbers of both kinds of organisms were present in the intestines of the other two animals. Of the two calves that did not respond to treatment with a mixture of phages B44/1 and B44/3, the one that died $24 \mathrm{~h}$ after infection had fairly high numbers of $E$. coli B44 and low numbers of phage B44/1-resistant mutants of $E$. coli B 44 in its small intestine, and the one that died at $46 \mathrm{~h}$ had low numbers of 
Table 6. Counts on the faeces of a colostrum-fed calf orally infected with $E$. coli B44 and treated with a mixture of phages B44/1 and B44/3 at the onset of diarrhoea

The numbers of $E$. coli $\mathrm{B} 44$, non-pathogenic $E$. coli $\mathrm{P} 713$, lactobacilli and phages given were as for Table 2 . The onset of diarrhoea usually occurred $15-18 \mathrm{~h}$ after infection with $E$. coli $\mathrm{B} 44$. The counts shown are representative of results obtained for 11 treated calves. $\mathrm{N}=$ none found.

Time after
treatment

(h)

0
2
4
6
9
19
30
48
144
168
240
336

No. of bacteria or phages $\left(\log _{10}\left[\right.\right.$ no. $\left.\left.(\mathrm{g} \text { faeces })^{-1}\right]\right)$

\begin{tabular}{ccccc}
\hline E. coli B44 & Phage B44/1-resistant & Total & & \\
& mutants of $E$. coli B44 & $E$. coli & Phage B44/1 & Phage B44/3 \\
$8 \cdot 2$ & $\mathrm{~N}$ & $8 \cdot 3$ & $\mathrm{~N}$ & $\mathrm{~N}$ \\
$8 \cdot 8$ & $\mathrm{~N}$ & $8 \cdot 8$ & $6 \cdot 3$ & $5 \cdot 7$ \\
$6 \cdot 5$ & $\mathrm{~N}$ & $6 \cdot 6$ & $9 \cdot 3$ & $6 \cdot 0$ \\
$7 \cdot 0$ & $\mathrm{~N}$ & $7 \cdot 0$ & $11 \cdot 4$ & $7 \cdot 8$ \\
$7 \cdot 0$ & $\mathrm{~N}$ & $7 \cdot 4$ & $11 \cdot 7$ & $10 \cdot 5$ \\
$6 \cdot 7$ & $5 \cdot 3$ & $9 \cdot 3$ & $11 \cdot 2$ & $10 \cdot 7$ \\
$5 \cdot 7$ & $6 \cdot 5$ & $9 \cdot 0$ & $10 \cdot 3$ & $10 \cdot 0$ \\
$4 \cdot 2$ & $6 \cdot 7$ & $9 \cdot 3$ & $10 \cdot 0$ & $10 \cdot 5$ \\
$4 \cdot 0$ & $4 \cdot 5$ & $8 \cdot 4$ & $3 \cdot 7$ & $8 \cdot 0$ \\
$3 \cdot 7$ & $4 \cdot 3$ & $8 \cdot 5$ & $\mathrm{~N}$ & $7 \cdot 5$ \\
$4 \cdot 3$ & $\mathrm{~N}$ & $8 \cdot 7$ & $\mathrm{~N}$ & $2 \cdot 5$ \\
$4 \cdot 0$ & $\mathrm{~N}$ & $8 \cdot 7$ & $\mathrm{~N}$ & $\mathrm{~N}$
\end{tabular}

both kinds of organisms both in this site and in the other parts of its alimentary tract. The faeces of the 11 calves that responded to treatment with phages B44/1 and B44/3 were examined at frequent intervals for 6-14 d; the results for one of the calves, a typical example, are summarized in Table 6. High numbers of $E$. coli B44 were present in their faeces at the time of treatment, where they usually comprised the majority of the total $E$. coli flora. By $4-8 \mathrm{~h}$, the numbers of this strain had decreased 10-100 fold; they continued to decline and then remained low for the rest of the examination period, very much lower than the total $E$. coli count. Phage B44/1-resistant mutants of $E$. coli $\mathrm{B} 44$ emerged in most of the calves, usually $16-20 \mathrm{~h}$ after treatment. In only one calf did their numbers become high, the increase being of short duration and accompanied by a co-incident recurrent episode of diarrhoea. The phages were detected in the faeces of 9 of the 11 calves $2 \mathrm{~h}$ after treatment. High concentrations of both phages were soon found in the faeces of all the calves, those of phage B44/1 always being found before those of phage B44/3. The faecal concentrations of both phages then remained high for 2 or $3 \mathrm{~d}$, after which they declined greatly, phage B44/3 being detected for longer (about $13 \mathrm{~d}$ ) than B44/1 (about $6 \mathrm{~d}$ ).

Another five colostrum-fed calves were treated with phages B44/1 and B44/3 at the onset of diarrhoea and examined $28 \mathrm{~h}$ later when they were clinically normal. Only low numbers of $E$. coli B44 and its phage B44/1-resistant mutant were found in the alimentary tract of these calves; much higher numbers of $E$. coli B44 were found in a comparable group of eight untreated colostrum-fed calves examined at point of death (Table 7). Fairly low numbers of the phages were found in the contents of the alimentary tracts of four of the five calves, phage B44/1 being more plentiful than phage B44/3. As in the colostrum-deprived calves, similar numbers of $E$. coli B44 and its phage B44/1-resistant mutants were usually found in the scrapings of the washed mucous membrane of the different parts of the small intestine of the 13 calves as we found in the intestinal contents; the number of phages was usually 10-100 times lower in the scrapings than in the contents. Another calf treated at the onset of diarrhoea was examined $8 \mathrm{~h}$, instead of $28 \mathrm{~h}$, later when it still had diarrhoea. The numbers of $E$. coli B44 in the contents of the abomasum, parts $1-7$ of the small intestine, and the colon were $\left(\log _{10} \mathrm{~g}^{-1}\right) 2 \cdot 3,2 \cdot 0,2 \cdot 0,2 \cdot 5,2 \cdot 7,3 \cdot 2,4 \cdot 2,4 \cdot 6$ and 6.0 respectively; no phage-resistant mutants were isolated. The corresponding figures for phage B44/1 were $4 \cdot 4,4 \cdot 0,5 \cdot 0,5 \cdot 0,6 \cdot 2,7 \cdot 3,8 \cdot 2,9 \cdot 0$ and $10 \cdot 0$ respectively and for phage B44/3 were $4 \cdot 4,4 \cdot 7,4 \cdot 7,4 \cdot 7,5 \cdot 7,6 \cdot 5,7 \cdot 5,8 \cdot 2$ and $9 \cdot 0$ respectively. The numbers of $E$. coli $\mathrm{B} 44$ were very much lower than they were in an untreated calf examined at the same time after infection as this calf. The counts in the contents of the abomasum, parts $1-7$ of the small intestine and the colon of this untreated calf were $\left(\log _{10} \mathrm{~g}^{-1}\right) 5 \cdot 2,7 \cdot 7,9 \cdot 3,9 \cdot 8,10 \cdot 0,10 \cdot 0,10 \cdot 0,10.0$ and 10.0 
Table 7. Counts on samples from colostrum-fed calves orally infected with E. coli B44 and treated or not treated with phages B44/1 and B44/3 at the onset of diarrhoea

The numbers of $E$. coli $\mathrm{B} 44$, non-pathogenic $E$. coli $\mathrm{P} 713$, lactobacilli and phages given were as for Table 2 . The onset of diarrhoea usually occurred $15-18 \mathrm{~h}$ after infection with $E$. coli $\mathrm{B} 44$. Five phage-treated calves were examined $28 \mathrm{~h}$ after treatment and eight untreated calves at point of death. The median count is given followed by the range in parentheses; $N=$ none found. In general the results for parts 2,4 and 6 of the small intestine were intermediate between those for parts 1 and 3,3 and 5 , and 5 and 7 respectively.

\begin{tabular}{|c|c|c|c|c|c|}
\hline & & nbers of bac & or phages (lo & $(\mathrm{g} \text { sample })^{-1}$ & \\
\hline & & Phage- & ed calves & & \\
\hline $\begin{array}{l}\text { Material } \\
\text { examined }\end{array}$ & E. coli $\mathrm{B} 44$ & $\begin{array}{c}\text { Phage } \mathrm{B} 44 / 1- \\
\text { resistant } \\
\text { mutants of } \\
\text { E. coli } \mathrm{B} 44\end{array}$ & Phage B44/1 & Phage B44/3 & $\begin{array}{l}\text { Untreated } \\
\text { calves } \\
\text { E. coli } \text { B44 }\end{array}$ \\
\hline $\begin{array}{l}\text { Abomasum } \\
\text { contents }\end{array}$ & $\mathrm{N}(\mathrm{N}-3 \cdot 0)$ & $\mathrm{N}(\mathrm{N}-2 \cdot 0)$ & $3 \cdot 3(\mathrm{~N}-5 \cdot 3)$ & $3.6(\mathrm{~N}-6.3)$ & $5 \cdot 2(\mathrm{~N}-8 \cdot 0)$ \\
\hline $\begin{array}{l}\text { Small intestine } \\
\text { contents, part: }\end{array}$ & & & & & \\
\hline 1 & $\mathrm{~N}(\mathrm{~N}-2 \cdot 5)$ & $\mathrm{N}(\mathrm{N}-\mathrm{N})$ & $2 \cdot 0(\mathrm{~N}-4 \cdot 6)$ & $2 \cdot 6(\mathrm{~N}-4 \cdot 5)$ & $6 \cdot 1(3 \cdot 0-9 \cdot 7)$ \\
\hline 3 & $2 \cdot 3(\mathrm{~N}-3 \cdot 2)$ & $\mathrm{N}(\mathrm{N}-5 \cdot 0)$ & $4 \cdot 7(\mathrm{~N}-7 \cdot 0)$ & $2 \cdot 7(2 \cdot 2-7 \cdot 7)$ & $9 \cdot 7(8 \cdot 3-10 \cdot 0)$ \\
\hline 5 & $4 \cdot 3(3 \cdot 0-5 \cdot 0)$ & $3 \cdot 3(\mathrm{~N}-5 \cdot 7)$ & $5 \cdot 6(2 \cdot 7-8 \cdot 5)$ & $4 \cdot 3(2 \cdot 7-8 \cdot 7)$ & $9.8(9 \cdot 4-10 \cdot 3)$ \\
\hline 7 & $5 \cdot 2(4 \cdot 5-6 \cdot 5)$ & $4 \cdot 0(3 \cdot 0-6 \cdot 0)$ & $7 \cdot 0(6 \cdot 0-9 \cdot 0)$ & $5 \cdot 4(5 \cdot 0-9 \cdot 0)$ & $9 \cdot 9(9 \cdot 4-10 \cdot 3)$ \\
\hline Colon & & & & & \\
\hline contents & $4 \cdot 5(4 \cdot 0-5 \cdot 0)$ & $3.9(3.0-5 \cdot 5)$ & $7 \cdot 0(6 \cdot 3-9 \cdot 5)$ & $6 \cdot 8(6 \cdot 2-9 \cdot 3)$ & $10 \cdot 1(9 \cdot 6-10 \cdot 8)$ \\
\hline Faeces & $4 \cdot 7(4 \cdot 6-5 \cdot 5)$ & $3.8(3.0-6.0)$ & $7 \cdot 0(4 \cdot 2-10 \cdot 3)$ & $7 \cdot 7(7 \cdot 0-9 \cdot 5)$ & $10 \cdot 0(9 \cdot 7-10 \cdot 5)$ \\
\hline Blood & $\mathrm{N}(\mathrm{N}-\mathrm{N})$ & $\mathbf{N}(\mathbf{N}-\mathbf{N})$ & $\mathrm{N}(\mathrm{N}-2 \cdot 8)$ & $\mathrm{N}(\mathrm{N}-2 \cdot 3)$ & $\mathrm{N}(\mathrm{N}-3 \cdot 5)$ \\
\hline
\end{tabular}

respectively. To determine the fate of phage particles in the alimentary tract of a diarrhoeic calf in the apparent absence of bacteria in which they could replicate, phages B44/1 and B44/3, at their usual dose, were given to a calf at the onset of diarrhoea induced by the oral adminstration of the $08: \mathrm{K} 85,99 \mathrm{E}$. coli enteropathogenic strain $\mathrm{S} 13$. When the calf was killed $28 \mathrm{~h}$ later, only low numbers of phage B44/1 and even lower numbers of phage B44/3 were found in its alimentary tract. The numbers of phage B44/1 in its abomasum, parts 1-7 of its small intestine, and its colon were $\left(\log _{10} \mathrm{~g}^{-1}\right) 2 \cdot 0,3 \cdot 7,3 \cdot 9,4 \cdot 0,4 \cdot 4,4 \cdot 7,4 \cdot 8,4 \cdot 6$ and 4.9. The corresponding figures for phage $\mathrm{B} 44 / 3$ were $2 \cdot 3,2 \cdot 5,2 \cdot 0,3 \cdot 0,3 \cdot 3,3 \cdot 3,3 \cdot 3$, and $3 \cdot 5$. Faecal samples from this calf had been collected on 10 different occasions before it was killed. On no occasion were the phages B44/1 and B44/3 present in numbers higher than $\left(\log _{10} \mathrm{~g}^{-1}\right) 5.2$ and 6.5 respectively.

\section{Behaviour of phage-resistant mutants of E. coli B44 in calves}

The results of examining a colostrum-deprived calf when it was near to death $27 \mathrm{~h}$ after it had been given equal numbers of $E$. coli $\mathrm{B} 44$ and of two laboratory-isolated mutants of this strain are summarized in Table 8; one of the mutants was resistant to phage B44/1 and one resistant to phages B44/2 and B44/3. In all parts of the intestines, $E$. coli B44 was about 10 times more numerous than the phage B44/2 and B44/3-resistant mutant and about 1000 times more numerous than the phage B44/1-resistant mutant. Similar results were obtained when the experiment was repeated in another two colostrum-deprived calves. The phage B44/1-resistant mutant given to one of these animals had been isolated from the small intestine of a phagetreated calf. Such a mutant was given to one colostrum-deprived and five colostrum-fed calves. The colostrum-deprived calf developed severe diarrhoea $15 \mathrm{~h}$ later and was close to death when examined at $27 \mathrm{~h}$; high numbers of the mutant were found in its small intestine. The colostrumfed calves showed little departure from normal health. One animal had a bout of diarrhoea at $42 \mathrm{~h}$ when the calves were killed for examination, but as only very low numbers of the E. coli B44 mutant were present in parts 1-6, and moderate numbers in part 7 , of its small intestine it seemed unlikely that the $E$. coli B44 mutant was responsible for the diarrhoea; only low numbers were also present in the small intestine of the other four colostrum-fed calves (Table 9). 
Table 8. Counts on the contents of the alimentary tract of a colostrum-deprived calf, near to death, $27 \mathrm{~h}$ after it had been given orally a mixture containing equal numbers of E. coli B44 and two mutants of it resistant to phage B44/1 and to phages B44/2 and B44/3

Non-pathogenic E. coli P713 and lactobacilli were also given (numbers as for Table 2).

\begin{tabular}{|c|c|c|c|}
\hline \multirow{2}{*}{$\begin{array}{c}\text { Material } \\
\text { examined }\end{array}$} & \multicolumn{3}{|c|}{ No. of bacteria $\left.\left(\log _{10}[\text { no. (g contents) })^{-1}\right]\right)$} \\
\hline & E. coli $\mathrm{B} 44$ & $\begin{array}{c}\text { Phage } \\
\text { B44/1-resistant } \\
\text { mutant }\end{array}$ & $\begin{array}{c}\text { Phage } B 44 / 2 \text { and } \\
\text { B44/3-resistant } \\
\text { mutant }\end{array}$ \\
\hline Abomasum contents & $5 \cdot 7$ & $5 \cdot 0$ & $5 \cdot 3$ \\
\hline $\begin{array}{l}\text { Small intestine } \\
\text { contents, part: }\end{array}$ & & & \\
\hline 1 & $10 \cdot 0$ & $6 \cdot 5$ & $8 \cdot 4$ \\
\hline 2 & $10 \cdot 0$ & $6 \cdot 6$ & $9 \cdot 0$ \\
\hline 3 & $10 \cdot 0$ & $6 \cdot 8$ & $9 \cdot 0$ \\
\hline 4 & $10 \cdot 3$ & $7 \cdot 0$ & $9 \cdot 0$ \\
\hline 5 & $10 \cdot 0$ & $7 \cdot 4$ & $9 \cdot 3$ \\
\hline 6 & $10 \cdot 4$ & $7 \cdot 5$ & $9 \cdot 3$ \\
\hline 7 & $10 \cdot 3$ & $7 \cdot 3$ & $9 \cdot 4$ \\
\hline Colon contents & $10 \cdot 3$ & $6 \cdot 7$ & $8 \cdot 7$ \\
\hline
\end{tabular}

Table 9. Counts on the contents of different parts of the alimentary tract of one colostrum-deprived calf and five colostrum-fed calves infected with a phage B44/1-resistant mutant of E. coli B44

The five colostrum-fed calves were examined $42 \mathrm{~h}$ after infection and the colostrum-deprived calf when near to death $27 \mathrm{~h}$ after infection. For other details see Table 3.

$\begin{array}{lcc}\begin{array}{c}\text { Material } \\ \text { examined }\end{array} & \overbrace{\begin{array}{c}\text { Colostrum-deprived } \\ \text { calf }\end{array}}^{\begin{array}{c}\text { No. of the mutant bacteria } \\ \left.\left(\log _{10}[\text { no. (g contents })^{-1}\right]\right) \text { in : }\end{array}} \begin{array}{c}\text { Colostrum-fed } \\ \text { calves }\end{array} \\ \begin{array}{c}\text { Abomasum contents } \\ \text { Small intestine }\end{array} & 7 \cdot 3 & 2 \cdot 0(\mathrm{~N}-3 \cdot 6) \\ \text { contents, part: } & & \\ 1 & 9 \cdot 2 & 2 \cdot 6(\mathrm{~N}-3 \cdot 5) \\ 2 & 8 \cdot 7 & 2 \cdot 7(\mathrm{~N}-4 \cdot 0) \\ 3 & 8 \cdot 7 & \mathrm{~N}(\mathrm{~N}-4 \cdot 6) \\ 4 & 9 \cdot 5 & 2 \cdot 0(\mathrm{~N}-5 \cdot 0) \\ 5 & 9 \cdot 3 & 2 \cdot 0(\mathrm{~N}-5 \cdot 5) \\ 6 & 9 \cdot 3 & 2 \cdot 0(\mathrm{~N}-6 \cdot 0) \\ 7 & 10 \cdot 0 & 3 \cdot 2(2 \cdot 7-7 \cdot 6) \\ \text { Colon contents } & 10 \cdot 0 & 5 \cdot 0(3 \cdot 7-7 \cdot 5)\end{array}$

Inoculation of calves with faeces from calves that had been infected with E. coli B44 and then treated with phages

To gain an impression as to whether or not the faeces of phage-treated calves would be a source of infection for healthy animals nine colostrum-fed calves were orally inoculated with a selection of faecal samples containing different amounts of E. coli B44 and phages B44/1 and B44/3. Six of the samples were from calves that had either recovered from, or were still suffering from, a phage-treated attack of $E$. coli B44 diarrhoea; three were from calves that had been given one or other of these six samples. All nine calves remained well and most had only very low numbers of $E$. coli B44 or phage B44/1-resistant mutants of it in their faeces $24 \mathrm{~h}$ after inoculation (Table 10). A tenth calf was given an inoculum of faeces from an untreated infected calf; the challenge dose $\left(\log _{10}=5 \cdot 0\right)$ of $E$. coli $\mathrm{B} 44$ was lower than that given to eight of the other nine calves. Even so, the animal developed diarrhoea $28 \mathrm{~h}$ after infection and died 28-36 h later. 
Table 10. The effect of challenging colostrum-fed calves with faecal samples of other calves that had been given E. coli B44 and phages B44/I and B44/3

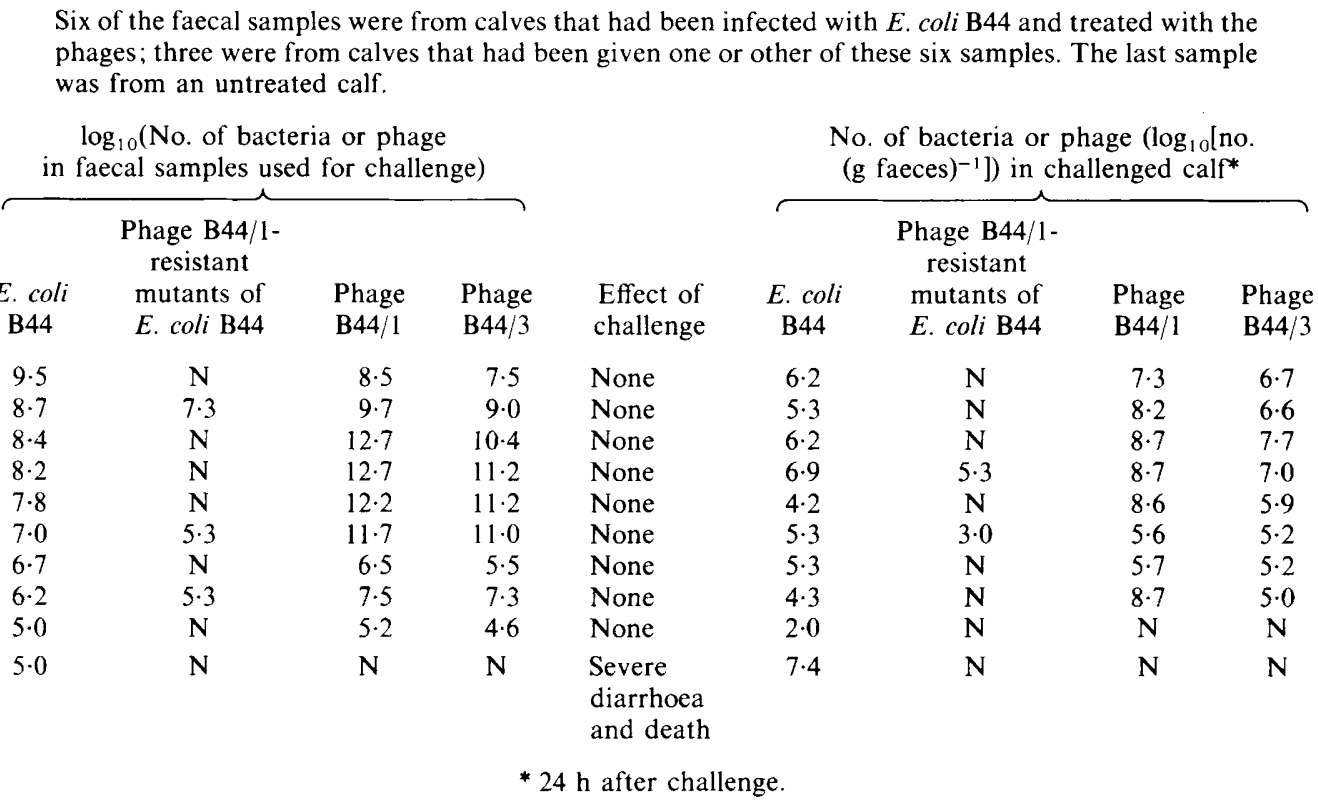

Another 10 calves were inoculated with faecal samples from $E$. coli $\mathrm{B} 44$-infected calves that had been treated with phages B44/1 and B44/2 instead of B44/1 and B44/3. Seven remained well. The remaining three developed diarrhoea, one severe and two mild cases, from which they recovered; their diarrhoeic episodes coincided with high faecal counts of phage B44/1-resistant mutants of E. coli B44.

Survival of E. coli B44 and phages B44/I and B44/2 in faecal samples from phage-treated calves

Four samples of faeces from different calves that had been infected with $E$. coli B44 and then treated with phages B44/1 and B44/2 were left exposed to the atmosphere in an unheated animal house and examined microbiologically at intervals afterwards. The bacteria and the phages survived for different periods of time in the different specimens but in each specimen the phages survived for at least $100 \mathrm{~d}$ longer than $E$. coli B 44 . The survival time of $E$. coli B 44 varied from 41 to $163 \mathrm{~d}$ and those of phages varied from 189 to $365 \mathrm{~d}$.

\section{Effect of phage treatment in piglets experimentally infected with E. coli P433}

The results of infecting seven piglets with $E$. coli $\mathrm{P} 433$ and then treating them at the onset of diarrhoea, 13-16 h later, with a mixture of phage P433/1 and phage P433/2 (the phage that was active on mutants of $E$. coli $\mathrm{P} 433$ resistant to phage P433/1 but not on $E$. coli $\mathrm{P} 433$ itself) are summarized in Table 11; so are those for seven untreated piglets from the same litters as the treated ones. All the untreated piglets became severely ill. Those that died in the early stages of the disease were markedly dehydrated. Dehydration was less obvious in the survivors, which became severely ataxic and mentally confused; if they had not been fed by stomach tube, all of them would have died. Apart from the diarrhoea, which soon terminated, the treated piglets showed little or no departure from normal health. Large amounts of $E$. coli P433 were found in the faeces of all 14 piglets at the onset of diarrhoea. In the treated piglets the counts had decreased considerably by $3 \mathrm{~h}$ and markedly by $8 \mathrm{~h}$; they usually remained very low thereafter, much lower than those of the total E. coli. Phage P433/1-resistant E. coli $\mathrm{P} 433$ organisms were first isolated at $8 \mathrm{~h}$ and by $11 \mathrm{~h}$ they were found in the faeces of several of the treated piglets; their numbers, though, were always low. High numbers of $E$. coli $\mathrm{P} 433$ were found in the faeces of all surviving untreated piglets for the first $72 \mathrm{~h}$, after which the numbers declined; very high 


\section{Table 11. Effect of giving phages P433/1 and P433/2 to piglets at the onset of diarrhoea caused} by E. coli $P 433$

The piglets were inoculated orally with $3 \times 10^{8}$ viable organisms of E. coli P433, together with $3 \times 10^{9}$ viable organisms of the non-pathogenic $E$. coli $\mathrm{P} 713$ and $10^{9}$ viable organisms of a lactobacillus strain. Phages P433/1 and P433/2 were given as a mixture containing $10^{10}$ viable particles of each. The onset of diarrhoea usually occurred $13-16 \mathrm{~h}$ after infection with E. coli P433.

$\begin{array}{lccl}\text { Piglets } & \text { No. } & \text { No. that died } & \text { Approx. duration of diarrhoea* }(\mathrm{h}) \\ \text { Treated } & 7 & 0 & 7,9,10,11,13(3) \\ \text { Untreated } & 7 & 4 & 26 \dagger, 28 \dagger, 33 \dagger, 44(2), 65 \dagger, 84\end{array}$

* The number of piglets, when this was $>1$, is given in parentheses.

† Until death.

numbers were present in the small intestine of the animals that died. High counts of phage P433/1 were found in the faeces of most of the treated piglets at $3 \mathrm{~h}$ and in the faeces of all of them at $5 \mathrm{~h}$. The numbers usually declined after $48 \mathrm{~h}$. At nearly all examinations, phage P433/2 was much less plentiful than phage P433/1. The results of examining the faeces of one of the treated piglets, a typical example, and an untreated litter-mate are summarized in Table 12.

Another two piglets were treated at the onset of diarrhoea with phage P433/1 instead of with a mixture of this phage and phage P433/2. Their diarrhoea ceased 8-22 h later, when both piglets appeared normal. The numbers of E. coli $\mathrm{P} 433$ in their faeces had decreased considerably by $24 \mathrm{~h}$ and they remained low thereafter. Mutants resistant to phage P433/1 were not found in the faeces of one animal and were found on 2 of 16 occasions in the faeces of the other, and then in only low numbers. Two untreated piglets from the same litter were examined after the onset of diarrhoea. One of these animals became severely ill and was near to death $46 \mathrm{~h}$ after the onset of diarrhoea; high numbers of $E$. coli $\mathrm{P} 433$ were found in its small intestine. The other animal had diarrhoea for $72 \mathrm{~h}$ during which time high numbers of $E$. coli P433 were present in its faeces.

Piglets were challenged with $E$. coli $\mathrm{P} 433$, treated with either phage $\mathrm{P} 433 / 1$ or a mixture of this phage and phage P433/2 at the onset of diarrhoea and examined $28 \mathrm{~h}$ later when they were normal (Table 13). Only low numbers of $E$. coli $\mathrm{P} 433$ and no phage P443/1-resistant mutants of it were found in the contents of the alimentary tracts of these animals. A piglet treated with phage P433/2 still had diarrhoea at that time, as severe as that in an untreated piglet; the numbers of $E$.

\section{Table 12. Counts on the faeces of two piglets infected with E. coli P433, one treated with a mixture of phages P433/1 and P433/2 at the onset of diarrhoea and the other not treated}

The two piglets were litter mates. The counts shown are representative of results obtained for seven treated piglets and their seven untreated litter mates; $\mathbf{N}=$ none found. The numbers of $E$. coli $\mathbf{P} 433$, non-pathogenic E. coli P713, lactobacilli and phages given were as for Table 11.

No. of bacteria or phages $\left(\log _{10}\left[\right.\right.$ no. $\left.\left.(\mathrm{g} \text { faeces })^{-1}\right]\right)$ in:

\begin{tabular}{|c|c|c|c|c|c|c|c|}
\hline \multirow{2}{*}{$\begin{array}{l}\text { Time after } \\
\text { onset of } \\
\text { diarrhoea* } \\
\text { (h) }\end{array}$} & \multirow[b]{2}{*}{$\begin{array}{c}\text { E. coli } \\
\text { P433 }\end{array}$} & \multirow{2}{*}{$\begin{array}{c}\text { Phage } \mathrm{P} 433 / 1- \\
\text { resistant } \\
\text { mutants of } \\
\text { E. coli } \mathrm{P} 433\end{array}$} & \multirow[b]{2}{*}{$\begin{array}{c}\text { Total } \\
\text { E. coli }\end{array}$} & \multirow[b]{2}{*}{$\begin{array}{l}\text { Phage } \\
\text { P433/1 }\end{array}$} & \multirow[b]{2}{*}{$\begin{array}{l}\text { Phage } \\
\text { P433/2 }\end{array}$} & \multicolumn{2}{|c|}{ Untreated piglet } \\
\hline & & & & & & $\begin{array}{l}\text { E. coli } \\
\text { P433 }\end{array}$ & $\begin{array}{l}\text { Total } \\
\text { E. coli }\end{array}$ \\
\hline 0 & $8 \cdot 5$ & $\mathbf{N}$ & $9 \cdot 2$ & $\mathbf{N}$ & $\mathbf{N}$ & $8 \cdot 4$ & $8 \cdot 5$ \\
\hline 3 & 6.9 & $\mathbf{N}$ & $7 \cdot 7$ & 8.6 & $7 \cdot 5$ & $9 \cdot 0$ & $9 \cdot 2$ \\
\hline 7 & 5.0 & $\mathrm{~N}$ & $8 \cdot 6$ & $9 \cdot 2$ & $8 \cdot 3$ & 9.0 & $9 \cdot 0$ \\
\hline 11 & $5 \cdot 8$ & $\mathrm{~N}$ & $9 \cdot 2$ & $9 \cdot 2$ & $8 \cdot 3$ & $9 \cdot 2$ & $9 \cdot 2$ \\
\hline 15 & $4 \cdot 0$ & $\mathrm{~N}$ & $8 \cdot 0$ & $8 \cdot 2$ & $6 \cdot 3$ & $9 \cdot 4$ & $9 \cdot 4$ \\
\hline 24 & $4 \cdot 6$ & $\mathrm{~N}$ & $9 \cdot 4$ & 6.7 & $5 \cdot 5$ & 9.6 & $9 \cdot 7$ \\
\hline 48 & $6 \cdot 5$ & $\mathrm{~N}$ & $9 \cdot 3$ & 8.9 & $5 \cdot 0$ & 8.4 & 8.8 \\
\hline 72 & 5.4 & $4 \cdot 5$ & $8 \cdot 7$ & $6 \cdot 5$ & $3 \cdot 3$ & 8.9 & $9 \cdot 2$ \\
\hline 96 & 5.0 & 4.0 & $8 \cdot 7$ & $6 \cdot 0$ & $\mathrm{~N}$ & $7 \cdot 7$ & $8 \cdot 3$ \\
\hline
\end{tabular}

\footnotetext{
* The onset of diarrhoea usually occurred 13-16 h after infection with E. coli P433.
} 
Table 13. Counts on the contents of the alimentary tract of piglets given E. coli P433, given phage P433/1 or a mixture of phages P433/1 and P433/2 at the onset of diarrhoea, and killed 28 h later

The dose of the phages in this experiment was reduced from the usual $10^{10}$ to $10^{9}$ viable particles. The numbers of E. coli $\mathrm{P} 433$, non-pathogenic E. coli $\mathrm{P} 713$ and lactobacilli given were as for Table 11 . The onset of diarrhoea usually occurred $13-16 \mathrm{~h}$ after infection with $E$. coli P433. No phage-resistant mutants of $E$. coli $\mathrm{P} 433$ were isolated from any of the piglets. In general the results for parts 2,4 and 6 of the small intestine were intermediate between those for parts 1 and 3, 3 and 5, and 5 and 7 respectively. $\mathrm{N}=$ none found.

$\begin{gathered}\text { Organisms } \\ \text { given }\end{gathered}$
E. coli $\mathrm{P} 433$
E. coli $\mathrm{P} 433$ and
phage $\mathrm{P} 433 / 1$
E. coli $\mathrm{P} 433$ and
phage $\mathrm{P} 433 / 2$
E. coli $\mathrm{P} 433$ and
phages $\mathrm{P} 433 / 1$ and
$\mathrm{P} 433 / 2$
E. coli $\mathrm{B} 44^{*}$ and
phages $\mathrm{P} 433 / 1$ and
$\mathrm{P} 433 / 2$

\begin{tabular}{|c|c|c|c|c|c|c|}
\hline \multirow{2}{*}{$\begin{array}{l}\text { Organisms } \\
\text { enumerated }\end{array}$} & \multirow[b]{2}{*}{ Stomach } & \multicolumn{4}{|c|}{ Small intestine, part: } & \multirow[b]{2}{*}{ Colon } \\
\hline & & 1 & 3 & 5 & 7 & \\
\hline E. coli $\mathrm{P} 433$ & $6 \cdot 0$ & 6.5 & $6 \cdot 7$ & 9.5 & $9 \cdot 7$ & $9 \cdot 5$ \\
\hline $\begin{array}{l}\text { E. coli } \mathrm{P} 433 \\
\text { Phage } \mathrm{P} 433 / 1\end{array}$ & $\begin{array}{l}5 \cdot 5 \\
5 \cdot 0\end{array}$ & $\begin{array}{l}3 \cdot 3 \\
4 \cdot 7\end{array}$ & $\begin{array}{l}4 \cdot 6 \\
5 \cdot 7\end{array}$ & $\begin{array}{l}5 \cdot 7 \\
8 \cdot 2\end{array}$ & $\begin{array}{l}5 \cdot 6 \\
8 \cdot 0\end{array}$ & $\begin{array}{l}6 \cdot 3 \\
8 \cdot 7\end{array}$ \\
\hline $\begin{array}{l}\text { E. coli } \mathrm{P} 433 \\
\text { Phage } \mathrm{P} 433 / 2\end{array}$ & $\begin{array}{l}6 \cdot 7 \\
\mathrm{~N}\end{array}$ & $\begin{array}{l}7 \cdot 0 \\
3.5\end{array}$ & $\begin{array}{l}9 \cdot 0 \\
3 \cdot 3\end{array}$ & $\begin{array}{r}10 \cdot 0 \\
3 \cdot 6\end{array}$ & $\begin{array}{r}10 \cdot 0 \\
3 \cdot 9\end{array}$ & $\begin{array}{l}9 \cdot 8 \\
4 \cdot 3\end{array}$ \\
\hline $\begin{array}{l}\text { E. coli } \mathrm{P} 433 \\
\text { Phage } \mathrm{P} 433 / 1 \\
\text { Phage } \mathrm{P} 433 / 2\end{array}$ & $\begin{array}{l}5 \cdot 5 \\
4 \cdot 5 \\
N\end{array}$ & $\begin{array}{c}\mathbf{N} \\
3 \cdot 0 \\
\mathbf{N}\end{array}$ & $\begin{array}{l}5 \cdot 5 \\
5 \cdot 5 \\
\mathrm{~N}\end{array}$ & $\begin{array}{l}4 \cdot 2 \\
4 \cdot 2 \\
3 \cdot 7\end{array}$ & $\begin{array}{l}6 \cdot 7 \\
6 \cdot 7 \\
3 \cdot 0\end{array}$ & $\begin{array}{l}7 \cdot 3 \\
7 \cdot 3 \\
3 \cdot 0\end{array}$ \\
\hline $\begin{array}{l}\text { Phage P433/1 } \\
\text { Phage P433/2 }\end{array}$ & $\begin{array}{l}3 \cdot 3 \\
3 \cdot 3\end{array}$ & $\begin{array}{l}3 \cdot 7 \\
4 \cdot 3\end{array}$ & $\begin{array}{l}3 \cdot 5 \\
3 \cdot 0\end{array}$ & $\begin{array}{l}2 \cdot 7 \\
2 \cdot 6\end{array}$ & $\begin{array}{l}3 \cdot 4 \\
\mathrm{~N}\end{array}$ & $\begin{array}{l}3 \cdot 4 \\
\mathrm{~N}\end{array}$ \\
\hline
\end{tabular}

*E. coli $\mathrm{B} 44$ given instead of E. coli $\mathrm{P} 433$

coli $\mathrm{P} 433$ in its small intestine, too, were as high as those in the small intestine of the untreated piglet. Very low amounts of phages P433/1 and P433/2 were found in the alimentary tract of another piglet that had been given these phages at the onset of diarrhoea produced by $E$. coli $\mathrm{B} 44$ instead of by $E$. coli P433. The numbers of phage P433/1 present were very much lower than in the $E$. coli $\mathrm{P} 433$-infected piglets that had been treated with that phage. Only low numbers of phage P433/2 were found in the piglets that had been treated with that phage (with or without phage P433/1). As in the calves, the numbers of the infecting $E$. coli strain in the scrapings of the

Table 14. Counts on the contents of the alimentary tract of piglets $31 \mathrm{~h}$ after challenge with E. coli P433 and/or a phage P433/1-resistant mutant of it

The challenge consisted of $E$. coli $\mathrm{P} 433$ alone (challenge A), E. coli $\mathrm{P} 433$ plus a phage $\mathrm{P} 433 / 1$-resistant mutant (challenge B) or the phage P433/1-resistant mutant alone (challenge C). Non-pathogenic E. coli and lactobacilli were also given (numbers as in Table 11). $\mathbf{N}=$ none found.

\begin{tabular}{|c|c|c|c|c|}
\hline \multirow[b]{3}{*}{$\begin{array}{c}\text { Material } \\
\text { examined }\end{array}$} & \multicolumn{4}{|c|}{ No. of stated $E$. coli $\left.\left(\log _{10}[\text { no. (g contents })^{-1}\right]\right)$ in challenge: } \\
\hline & A & & & $\mathrm{C}$ \\
\hline & E. coli $\mathrm{P} 433$ & E. coli $\mathrm{P} 433$ & $\begin{array}{l}\text { Phage P433/1- } \\
\text { resistant mutant }\end{array}$ & $\begin{array}{l}\text { Phage P433/1- } \\
\text { resistant mutant }\end{array}$ \\
\hline mach contents & $4 \cdot 5$ & $5 \cdot 2$ & $5 \cdot 3$ & $5 \cdot 0$ \\
\hline 1 & $5 \cdot 4$ & $4 \cdot 6$ & 3.9 & $\mathrm{~N}$ \\
\hline 2 & $5 \cdot 0$ & $4 \cdot 0$ & $\mathrm{~N}$ & $N$ \\
\hline 3 & $5 \cdot 6$ & $5 \cdot 0$ & $4 \cdot 7$ & $\mathrm{~N}$ \\
\hline 4 & 6.4 & 9.0 & $5 \cdot 8$ & $\mathrm{~N}$ \\
\hline 5 & 9.7 & $10 \cdot 0$ & $5 \cdot 7$ & $4 \cdot 3$ \\
\hline 6 & 9.7 & $9 \cdot 8$ & $4 \cdot 2$ & $5 \cdot 0$ \\
\hline 7 & $9 \cdot 7$ & 9.9 & 5.8 & 6.8 \\
\hline lon contents & 9.8 & $9 \cdot 6$ & $6 \cdot 0$ & $7 \cdot 0$ \\
\hline
\end{tabular}


washed mucous membrane of the different parts of the small intestine of the piglets were similar to those in the intestinal contents whereas the numbers of phage were lower in the scrapings than in the contents. Similar results to those shown in Table 13 were obtained in examinations of another group of six piglets infected with $E$. coli $\mathrm{P} 433$, in which two were treated with phage $\mathrm{P} 433 / 1$, two were treated with phages P433/1 and P433/2, and two were not treated.

The results of an experiment comparing the ability of E. coli P433 and a phage P433/1resistant mutant of it to proliferate in the alimentary tract of piglets, singly or together, are illustrated in Table 14. The mutant had been isolated from a piglet treated with phage P433/1. The piglets infected with $E$. coli $\mathrm{P} 433$ (challenge A) or with this strain and its mutant (challenge B) developed severe diarrhoea. The animal that had received the mutant alone (challenge C) showed no departure from normal health and only low numbers of the mutant were found in its small intestine. The mutant was also present in sparse amounts in the small intestine of the piglet to which it had been given along with E. coli $\mathrm{P} 433$ (challenge B). Very much higher numbers of $E$. coli $\mathrm{P} 433$ were present in the small intestine of this piglet and in the small intestine of the piglet given E. coli $\mathrm{P} 433$ alone (challenge A).

\title{
Effect of phage treatment in lambs experimentally infected with E. coli $S 13$
}

Seven pairs of twin lambs were orally inoculated with E. coli S13 and, $8 \mathrm{~h}$ later, one lamb of each pair was given either $10^{9}$ or $10^{10}$ viable particles of the S13 phage. At 24 h the 14 lambs

\section{Table 15. Counts on the contents of the alimentary tract of twin lambs that had been infected} with $E$. coli $S 13$ and one of each pair given phage $S 138$ later

\begin{abstract}
The lambs were inoculated orally with $3 \times 10^{8}$ viable organisms of $E$. coli S13, $3 \times 10^{9}$ viable organisms of the non-pathogenic $E$. coli $\mathrm{P} 713$ and $10^{9}$ viable organisms of lactobacilli. Twin lambs were challenged identically. One of each pair of lambs received phage $\left(10^{9}\right.$ viable particles to nos $1-4$ and $10^{10}$ to nos 5-7) $8 \mathrm{~h}$ after infection, and were designated ' $a$ '; the lambs that did not receive phage were designated ' $b$ '. All the lambs were killed for examination $24 \mathrm{~h}$ after they had been infected. In general the results for parts 2, 4 and 6 of the small intestine were intermediate between those for parts 1 and 3,3 and 5 and 5 and 7 respectively.
\end{abstract}

\begin{tabular}{|c|c|c|c|c|c|c|c|}
\hline \multirow{3}{*}{$\begin{array}{l}\text { No. of } \\
\text { lamb }\end{array}$} & \multirow{3}{*}{$\begin{array}{l}\text { Organisms } \\
\text { enumerated }\end{array}$} & \multicolumn{6}{|c|}{ No. of bacteria or phage $\left(\log _{10}\left[\right.\right.$ no. $\left.\left.(\mathrm{g} \text { contents })^{-1}\right]\right)$ in: } \\
\hline & & \multirow[b]{2}{*}{ Abomasum } & \multicolumn{4}{|c|}{ Small intestine, part: } & \multirow[b]{2}{*}{ Colon } \\
\hline & & & 1 & 3 & 5 & 7 & \\
\hline \multirow[t]{2}{*}{ la } & E. coli $\mathrm{S} 13$ & $4 \cdot 0$ & $6 \cdot 2$ & $5 \cdot 0$ & $5 \cdot 7$ & $3 \cdot 3$ & $4 \cdot 3$ \\
\hline & Phage S13 & $4 \cdot 8$ & $6 \cdot 0$ & $6 \cdot 7$ & $7 \cdot 8$ & $9 \cdot 6$ & $8 \cdot 8$ \\
\hline $1 b$ & E. coli $\mathrm{S} 13$ & 7.6 & $9 \cdot 3$ & $10 \cdot 0$ & $10 \cdot 0$ & $10 \cdot 5$ & $10 \cdot 0$ \\
\hline \multirow[t]{2}{*}{$2 a$} & E. coli $\mathrm{S} 13$ & $5 \cdot 8$ & 6.0 & 6.0 & $5 \cdot 8$ & $6 \cdot 3$ & $7 \cdot 0$ \\
\hline & Phage S13 & $6 \cdot 0$ & $6 \cdot 6$ & $6 \cdot 6$ & $7 \cdot 0$ & $8 \cdot 0$ & $8 \cdot 3$ \\
\hline $2 b$ & E. coli $\mathrm{S} 13$ & $6 \cdot 0$ & $7 \cdot 0$ & $9 \cdot 0$ & $9 \cdot 8$ & $10 \cdot 0$ & $9 \cdot 4$ \\
\hline \multirow[t]{2}{*}{$3 a$} & E. coli $\mathrm{S} 13$ & $6 \cdot 7$ & $6 \cdot 8$ & $6 \cdot 8$ & $6 \cdot 8$ & $8 \cdot 7$ & $9 \cdot 3$ \\
\hline & Phage S13 & $5 \cdot 5$ & $5 \cdot 5$ & $5 \cdot 5$ & $6 \cdot 5$ & $8 \cdot 0$ & $8 \cdot 3$ \\
\hline $3 b$ & E. coli $\mathrm{S} 13$ & $7 \cdot 3$ & $7 \cdot 7$ & $8 \cdot 0$ & $9 \cdot 8$ & $10 \cdot 0$ & $9 \cdot 8$ \\
\hline \multirow[t]{2}{*}{$4 a$} & E. coli $\mathrm{S} 13$ & $4 \cdot 3$ & $5 \cdot 3$ & $6 \cdot 3$ & $7 \cdot 0$ & $9 \cdot 0$ & $9 \cdot 3$ \\
\hline & Phage S13 & $5 \cdot 0$ & $5 \cdot 3$ & $6 \cdot 4$ & $8 \cdot 0$ & $8 \cdot 5$ & $8 \cdot 3$ \\
\hline $4 b$ & E. coli $\mathrm{S} 13$ & $7 \cdot 5$ & $7 \cdot 8$ & $9 \cdot 7$ & $9 \cdot 5$ & $9 \cdot 5$ & $9 \cdot 4$ \\
\hline \multirow[t]{2}{*}{$5 a$} & E. coli $\mathrm{S} 13$ & $6 \cdot 3$ & $6 \cdot 3$ & $6 \cdot 3$ & $6 \cdot 0$ & $6 \cdot 0$ & $7 \cdot 3$ \\
\hline & Phage S13 & $6 \cdot 7$ & $7 \cdot 3$ & $7 \cdot 5$ & $7 \cdot 7$ & $9 \cdot 7$ & $9 \cdot 7$ \\
\hline $5 b$ & E. coli $\mathrm{S} 13$ & $6 \cdot 7$ & $7 \cdot 3$ & $7 \cdot 6$ & $9 \cdot 0$ & $9 \cdot 7$ & $9 \cdot 4$ \\
\hline \multirow[t]{2}{*}{$6 a$} & E. coli $\mathrm{S} 13$ & $5 \cdot 0$ & $5 \cdot 0$ & $5 \cdot 3$ & $5 \cdot 4$ & $7 \cdot 4$ & $8 \cdot 0$ \\
\hline & Phage S13 & $6 \cdot 3$ & $5 \cdot 4$ & $7 \cdot 0$ & $7 \cdot 5$ & $8 \cdot 8$ & $9 \cdot 0$ \\
\hline $6 \mathrm{~b}$ & E. coli $\mathrm{S} 13$ & $6 \cdot 6$ & $7 \cdot 3$ & $8 \cdot 3$ & $9 \cdot 7$ & $9 \cdot 6$ & $9 \cdot 3$ \\
\hline \multirow[t]{2}{*}{$7 \mathrm{a}$} & E. coli $\mathrm{S} 13$ & $5 \cdot 3$ & $5 \cdot 0$ & $5 \cdot 3$ & $6 \cdot 4$ & $7 \cdot 8$ & $9 \cdot 3$ \\
\hline & Phage S13 & $7 \cdot 3$ & $7 \cdot 0$ & $8 \cdot 0$ & $8 \cdot 3$ & $9 \cdot 0$ & $8 \cdot 3$ \\
\hline $7 b$ & E. coli S13 & $6 \cdot 8$ & $7 \cdot 5$ & $8 \cdot 3$ & $9 \cdot 0$ & $9 \cdot 7$ & $10 \cdot 0$ \\
\hline
\end{tabular}


were killed and the numbers of $E$. coli $\mathrm{S} 13$ and phage $\mathrm{S} 13$ in the alimentary tract were estimated (Table 15). At this time, two of the seven untreated lambs, nos $1 \mathrm{~b}$ and $6 \mathrm{~b}$, had just died and the other five in the untreated group had severe diarrhoea with clinical signs of dehydration; all seven had very high numbers of $E$. coli 13 in the small intestine, especially in the posterior part. Two of the four lambs given $10^{9}$ viable particles of phage $S 13$ (nos 1a and 2a) and one of the three given $10^{10}$ viable particles (no. 5a) were normal and they had only low numbers of E. coli S13 in their small intestine. Another of the lambs given $10^{10}$ viable particles of phage S13 (no. 6a) had mild diarrhoea and it, too, had only low numbers of $E$. coli $\mathrm{S} 13$ in its small intestine. The diarrhoea in the remaining three treated lambs was more marked, especially in the two given $10^{9}$ viable particles of phage S13 (nos 3a and 4a) but they showed no clinical signs of dehydration; the numbers of $E$. coli S13 in their small intestine were higher than those in the other treated lambs. In all seven pairs of twins, the numbers of $E$. coli $\mathrm{S} 13$ in the small intestine were very much lower in the treated twin than in the corresponding untreated twin; no mutants of $E$. coli S13 resistant to phage S13 were isolated from the treated lambs. The numbers of phage S13 in the alimentary tract of the treated lambs did not vary greatly from lamb to lamb.

Equal numbers of $E$. coli S13 and of a laboratory-isolated mutant of it resistant to phage S13 were given to a single lamb. When this lamb was killed $24 \mathrm{~h}$ later, the mutant was much less common in the intestine than $E$. coli $\mathrm{S} 13$; in the middle and lower small intestine the mutant was about 100 times less numerous than $E$. coli $\mathrm{S} 13$.

\section{DISCUSSION}

The results of this study showed that most calves inoculated with $E$. coli B44 and given phages B44/1 and B44/2 either 1 or $8 \mathrm{~h}$ later were protected from diarrhoea and death because the degree of destruction of the infecting $E$. coli strain by the phages was sufficient to prevent the bacteria becoming established in sufficiently high numbers in the small intestine. This was so even in the colostrum-deprived calves in which the destructive effect of the phages could not have been augmented by the anti-bacterial activity of colostral immunoglobulins. It appeared also that phage B44/1 was much more virulent than B44/2 in vivo, as it was in vitro. The in vitro tests probably underestimated the in vivo virulence of phage B44/1. Clinical response to treatment with phages B44/1 and B44/2 was much poorer when treatment was delayed until diarrhoea commenced. Most of these calves examined at death had high numbers of $E$. coli B44 mutants resistant to phage $\mathrm{B} 44 / 1$ in their small intestine. It is probable that death resulted from the failure of phage $B 44 / 2$ to control proliferation of these mutants even though the mutants were of reduced virulence to the extent that they did not proliferate in the small intestine and cause diarrhoea when given to healthy colostrum-fed calves. Much better results were obtained in calves treated at the onset of diarrhoea by replacing phage B44/2 with phage B44/3, the phage that in vitro was less active against $E$. coli $\mathrm{B} 44$ but more active against phage B44/1-resistant mutants of it. Following treatment, the high numbers of E. coli B44 in the faeces of these calves rapidly decreased and the organism was not replaced by phage B44/1-resistant mutants. The presence of only low numbers of $E$. coli B44 and its mutant in the contents of the small intestine of calves killed 8 and $28 \mathrm{~h}$ after treatment confirmed the efficiency of the combination of phages B44/1 and B44/3 in bringing the proliferation of both these organisms under control. The equally low numbers of the organisms in the scrapings of the washed mucous membrane of the small intestine of these calves indicated that the phages were as active against organisms adhering to the epithelium of the intestine as they were against organisms in its lumen. Only low numbers of both kinds of organisms were also found in one of the two calves that died following treatment with phages B44/1 and B44/3 and in a few of those that died following treatment with phages $\mathrm{B} 44 / 1$ and $\mathrm{B} 44 / 2$. This implies that the disease process in these calves was too far advanced to be reversible by the time the numbers of the infecting organisms were reduced by phage action.

Because phage B44/3 had to be given with phage B44/1 to effectively treat $E$. coli B44 infection in calves, a similar strategy was employed in the studies on the treatment of $E$. coli P433 diarrhoea in piglets, by including both phages P433/1 and P433/2 in the phage inoculum. Subsequent studies, though, suggested that equally good results could be obtained by giving 
phage $\mathrm{P} 433 / 1$ alone. This was because the emergence of mutants of E. coli $\mathrm{P} 433$ resistant to this phage did not constitute a problem, therefore negating the need for phage P433/2, which had been originally included in the inoculum specifically to control their proliferation. That mutants did not constitute a problem in the piglets as they had in the calves might have been due to the fact that the disease produced in calves by $E$. coli B44 was more severe than that produced in piglets by $E$. coli $\mathrm{P} 433$. Alternatively, or additionally, the $E$. coli $\mathrm{B} 44$ mutants could have been more virulent for calves than the $E$. coli $\mathrm{P} 433$ mutants were for piglets. Both mutants were fairly common in cultures of their parent strains. Phage S13-resistant mutants were uncommon in cultures of E. coli $\mathrm{S} 13$ and this may explain why they were never isolated from lambs treated with phage S13. The fact that $E$. coli S13 mutants, like the $E$. coli B44 and P433 mutants, were less virulent than their parent strains could also have contributed to our failure to isolate them in vivo.

In studies on generalized $E$. coli infection of mice (Smith \& Huggins, 1982) phage treatment was generally superior to antibiotic treatment. Although no such comparisons were made, it became apparent that phage treatment had several potential advantages over antibiotic treatment in the enteric $E$. coli infections reported here. The most obvious advantage is that phages need only to be given as one dose. Whereas the concentration of an antibiotic at the site of an infection will decrease from the moment of application, the amount of phage at the site should increase and the phage should become more effective from that moment because it will replicate in the susceptible bacterial cells proliferating there. It will only decrease in numbers when it has brought about the destruction of the mass of those cells. Resistant bacteria that emerge in an antibiotic-treated animal are probably similar in virulence to the parent strain. The resistant mutants that emerged in the phage-treated animals were markedly less virulent than their parent strains, the decreased virulence probably being associated with loss of specific $\mathrm{K}$ antigens, which are known to be involved in the virulence of enteropathogenic $E$. coli. Another advantage of phage over antibiotics was revealed by the finding that calves inoculated with faecal specimens from $E$. coli B44-infected calves that had been treated with phage B44/1 and B44/3, and from calves that had been inoculated with the faeces of these treated calves, remained healthy despite the fact that these specimens contained sufficient $E$. coli B44 to cause diarrhoea and death. This would not apply in the case of antibiotic-treated animals and it implies that there would be little danger of susceptible animals contracting disease from infected animals with which they were in contact or from premises in which they had been kept, provided the infected animals had been given phage; the phage, in fact, would protect them from clinical infection. Added support for this view was obtained from the observation that when the faeces of phage-treated E. coli B44-infected calves were exposed in an animal house the phage they contained survived longer than the $E$. coli B44. A wider implication of the finding, bearing in mind that the phage-resistant mutants were of only low virulence, is that the more a suitable phage is used in an infected community the better will be the control of clinical disease in that community. In fact, a case can be made for deliberately distributing phages in 'high-risk' environments.

On the basis of the results of the present work, one handicap to the practical use of phages in controlling $E$. coli diarrhoea might be the narrow range of their activity. The attack points of our principal phages were either the specific $\mathrm{K}$ antigens or structures closely associated with them. If phages could be found whose attack points were more widely distributed in enteropathogenic strains of $E$. coli they would have a greater degree of acceptance. Such attack points might be the adhesive factors, like 88, 99 and 987P in animal strains and CFAI and CFAII in human strains; it may be hoped that resistant mutants that emerged during treatment with these phages would lack these factors and, as a consequence, be of greatly reduced virulence. Whatever may be the case, the present study certainly establishes the possibility of using phages to control enteric $E$. coli infections. Highly virulent phages with a wide spectrum of activity against enteropathogens and with virulence factors as attack points might indeed have a part to play in the control of this kind of infection in domestic animals and man and in related infections such as cholera. Such phages could be used for curing infected individuals, for preventing them becoming a source of clinical infection for susceptible individuals and for disseminating in 'high-risk' environments. 
We are grateful to Miss Teresa Winstanley for her capable technical help. Our thanks are also due to Professor P. M. Biggs, Miss Margaret Lovell, Mrs Debra Wheatley and Dr B. Rowe for assistance in a variety of ways.

\section{REFERENCES}

ASCHAFFENBURG, R. (1949). The nutritive value of colostrum for the calf. 3 . Changes in the serum protein of the newborn calf following the ingestion of small quantities of the non-fatty fraction. British Journal of Nutrition 3, 200-204.

Miles, A. A. \& MisRa, S. S. (1938). The estimation of the bactericidal power of blood. Journal of Hygiene 38, 732-749.

Smith, H. Williams \& Halls, S. (1967). Observations by the ligated intestinal segment and oral inoculation methods on Escherichia coli infections in pigs, calves, lambs and rabbits. Journal of Pathology and Bacteriology 93, 499-529.
Smith, H. Williams \& Huggins, M. B. (1978). The influence of plasmid-determined and other characteristics of enteropathogenic Escherichia coli on their ability to proliferate in the alimentary tracts of piglets, calves and lambs. Journal of Medical Microbiology 11, 471-492.

Smith, H. Williams \& Huggins, M. B. (1982). Successful treatment of experimental Escherichia coli infections in mice using phage: its general superiority over antibiotics. Journal of General Microbiology 128, 307-318. 